\title{
أثر استخدام الأنشطة القائمة علي منهج \\ ريجيو اميليا في تنمية بعض مهارات التواصل \\ الاجتماعي لدي طفل الروضية
}

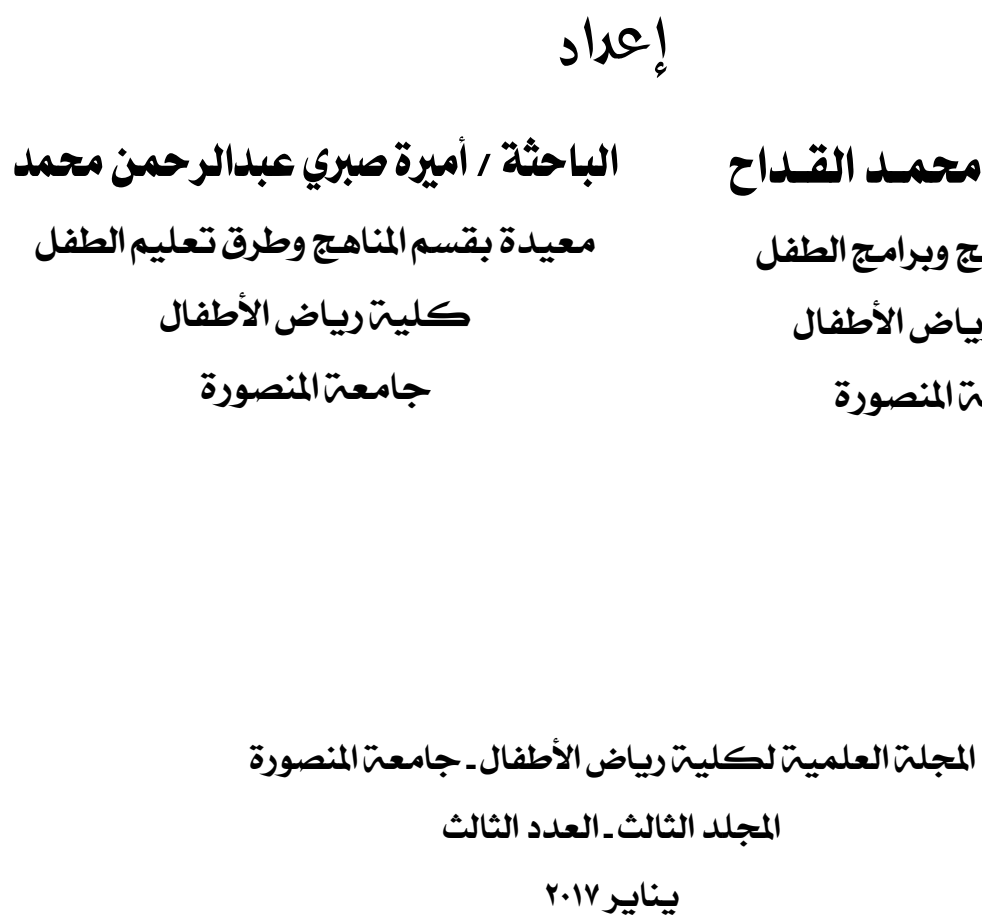$$
\text { ! إعراد }
$$$$
\text { الباحثة / أميرة صبري عبدالرحمن محمد }
$$$$
\text { معيدة بقسم المناهج وطرق تعليم الطفل }
$$$$
\text { كليتر رياض الأطفال }
$$

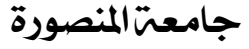

المجلت العلميت لكليت رياض الأطفال ـجامعت المنصورة

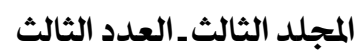

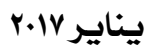$$
\text { أ.د/أمــل محمـد القــلاح }
$$$$
\text { أستاذ مناهـج وبرامج الطفل }
$$$$
\text { كليتررياض الأطفال }
$$

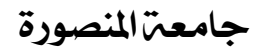




\title{
أثر استخدام الأنشطة القائمة علي منهج

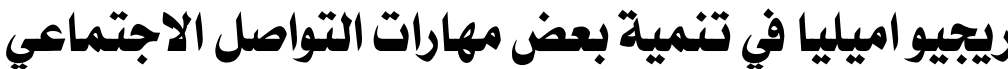

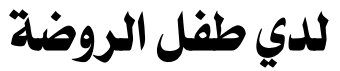

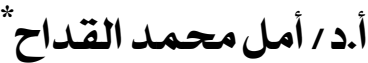

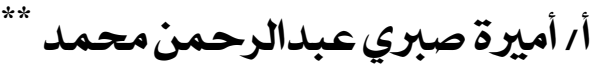

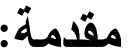

تعتبر مرحلة الطفولة من المراحل المميزة في تكوين شخصية الطفل،حيث يكتسب فيها العديد من المفاهيم و المهار ات التي تساعده على تحديد شخصيته، وصياغة شكل مستقبله، ويتم ذلك من خلال تفاعله مع البيئة المحيطة به سو اء داخل الروضة أو خارجها وفي هذه المرحلة يكتسب الطفل الكثير من المعلومات، وتتكون لايه المفاهيم المعرفية المختلفة التي تساعده على اللحاق بهذا الركب الهائل من المعلومات وخصوصناً أننا نعيش في عصر الانفجار المعرفي، ولذلك تؤكد الاتجاهات المعاصرة في تربية الطفل على أهمية تعريض الطفل للمواقف الحياتية المختلفة، و إكسابه المفاهيم المناسبة بما يساعده على اللحاق بهذه التطورات المعاصرة ، حيث يتسم العصر الذي نعيش فيه بالتغيرات

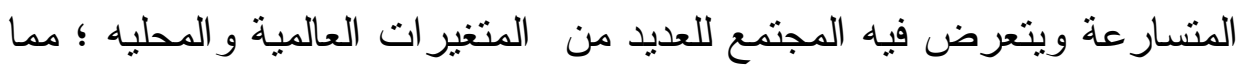
يستوجب إعادة النظر في المناهج التعليمية بحيث تتتاسب ونتو افق مع هذه

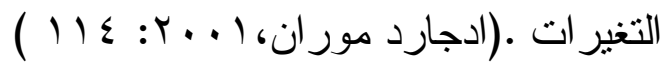

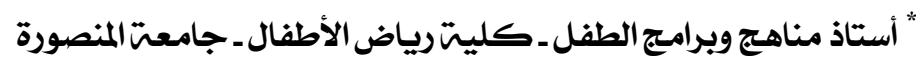

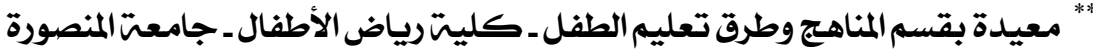


ونظر الزيادة وتيرة التغير في الحياة وأصبح من الصعب أن تواكب

المؤسسات هذا التغير ، فان ذلك يقتضي الاهتمام باكتساب الأطفال المهارات

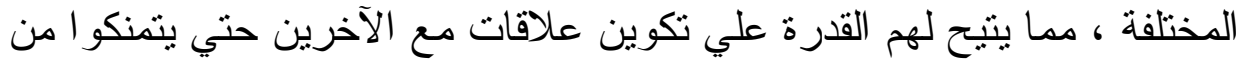
الاضطلاع بالتحديات التي تضعها الحياة في طريقهم. فالعمل مع الأطفال يتطلب تحديا كبير ا ،ومن أجل الاحتفاظ بمقار الحماس والاهتمام بنفسه ينبغي علينا

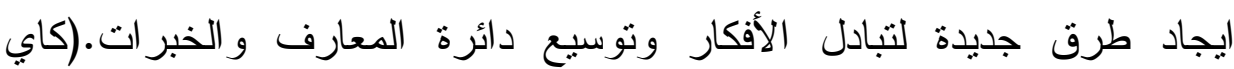

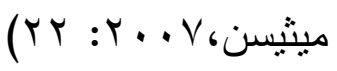

ومن المنقق عليه أن عملية التربية تؤتي ثمارها اذا تمت من خلال مو اقف عملية يمر بها الطفل خلال نموه وتفاعله مع محيطه من الناس و الأثياء، فليس المهم هو مقدار ما يفعله المعلم للطفل ،و انما المهم هو ما يقوم به الطفل نفسه، ومن أهم المطالب الرئيسية لطفل الروضة مر اعاة احتياجاته الاجتماعية

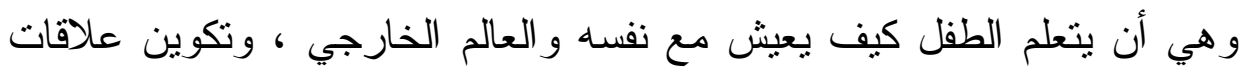
مع الآخرين و الاعتماد علي النفس وتحمل المسئولية. (حنان عبدالحميد العناني، (19:\% :...

ويمكن توضيح أن اكتساب الطفل للمهار ات الاجتماعية يساعده علي تنظيم

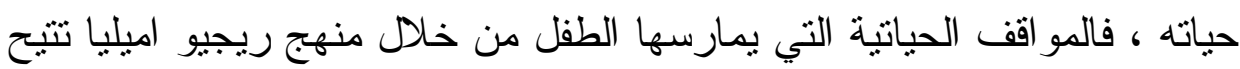

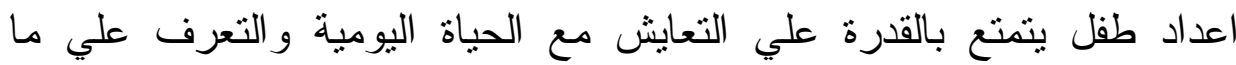
يو اجها من تحديات تحتاج لمهارات مثل القدرة علي التخطيط ، و القدرة علي لإني

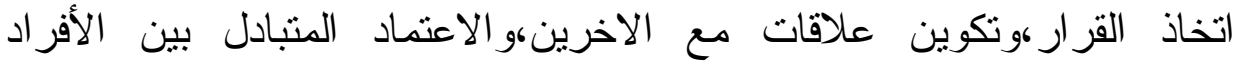
الآخرين(13: 2008, DOROTHY H. COHEN,et) ويؤكد ما سبق ما توصلت إليه دراسة (لمياء الصغير ،ج ( • ب)، ودر اسة كارين بيتي (Karen Petty, 2009) من أن اكتساب الطفل للمفاهيم الاجتماعية 
يتيح له إدر الك العلاقات الاجتماعية والتعامل مع الآخرين، و القدرة علي تحمل

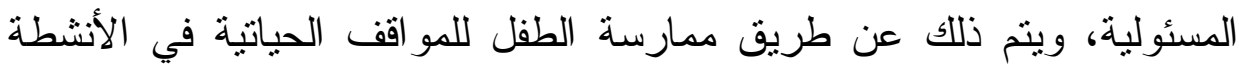
المقدمة له، و لابد من استخدام طرق و وأساليب حديثة لاكتساب الأطفال المفاهيم الاجتماعية. ومن الطرق و المناهج الحديثة للتعامل مع الأطفال منهج ريجيو اميليا

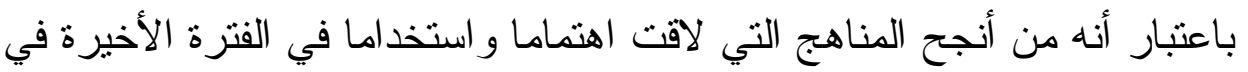
الأوساط التعليمية المهنية العالمية المهتمة بتربية الطفل.

ويعتمد منهج ريجيو اميليا علي بعض المبادئ الرئيسية في تعليم طفل

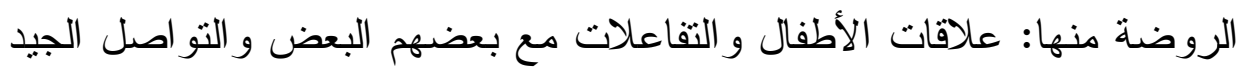

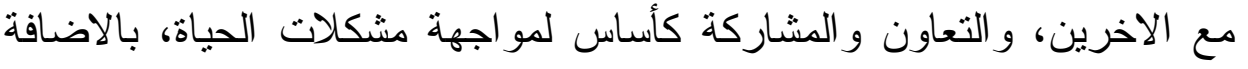

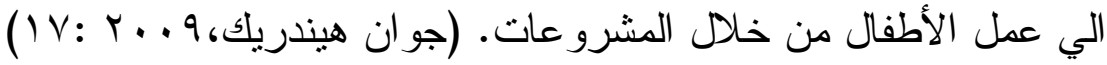
وينظر ريجيواميليا للأطفال كأفراد ذو مهارات وقدرات و اهتمامات ومو اهب متعددة ، ويتيح للمعلمة التخطيط للأنشطة والخبرات من خلال عمل

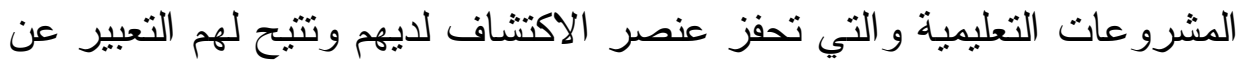

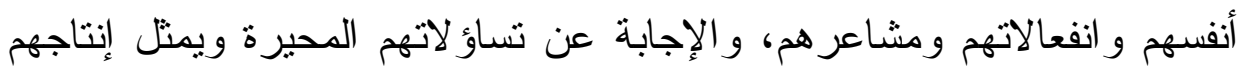
العلمي فههم و استيعابهم للخبرة التي يمرون بها من خلال اللغات الرمزية

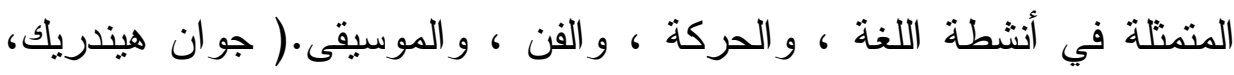

(Tr: $:$. . 9

ويعكس منهج "ريجيو اميليا" نظريات "جون ديوى وجان بياجيه" و "فيجونسكى" و "برونر" و النظرية البنانية ونظرية جاردنر للاكاءات المتعددة

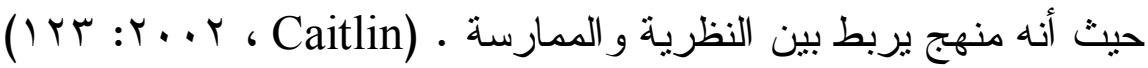
حيث تتاسس موضوعاته على المشاكل الو اقعية و المواقف الحياتية ، وتجيب على الأسئلة التي تتخل ذهن الطفل وميوله و اهتماماته الاجتماعية، و ولئه 
الذى اكدته عدد من الدراسات التزبويه (Franca,2007 )، (Susan,2005)،

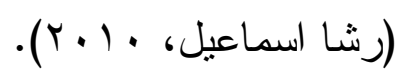

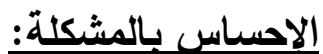

ظهر الإحساس بمشكلة الدراسة من خلال عده مؤشر ات منها:

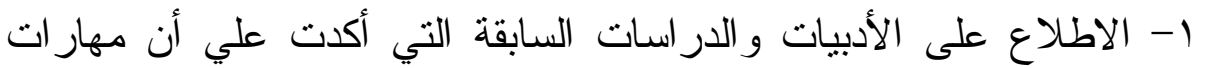

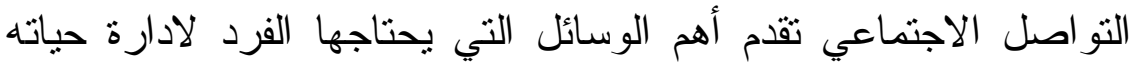

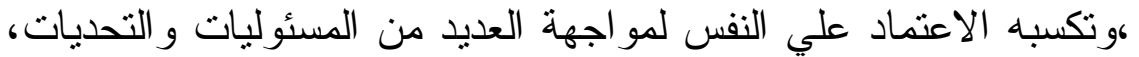

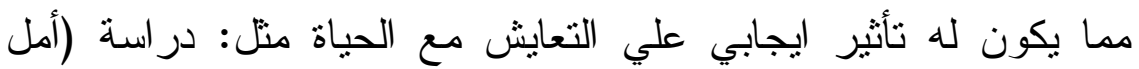

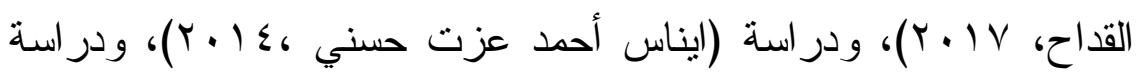

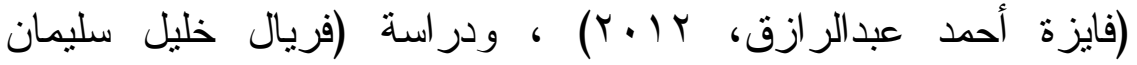

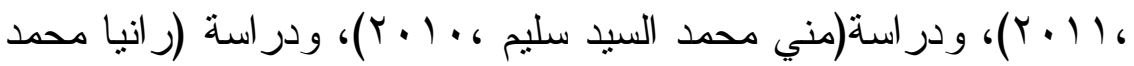

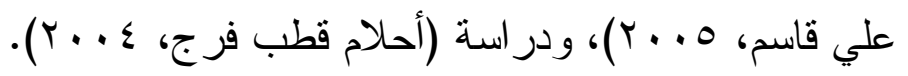

r- الدراسات التي اهتمت بمنهج ريجيو اميليا لطفل الروضة وأوصت

بتطبيقه نظر الأهميته ونجاحه في تدريب المتعلمين علي اكتساب ونتمية الهية

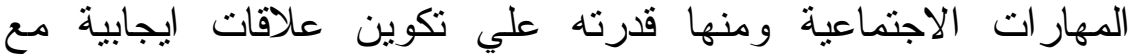
الاخرين، وعلي التعامل مع المشكلات بثقة و اقتدار مثل : در اسة (فاطمة

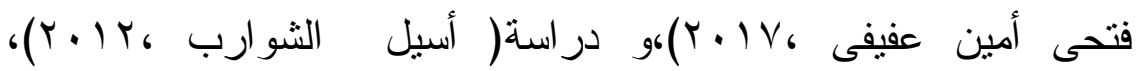
ودر اسة (Jana Strickler, 2012)، ودراسة (رشا اسماعيل خليل، • ( • (Y)، ودر اسة (Susan Clarke, 2005). ץ- نوصيات بعض المؤتمرات التي اتفقت على أهمية تطوير منهج رياض

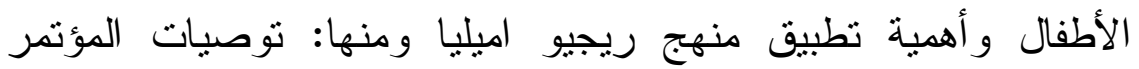
الدولي الثاني الخاص بتجربة ريجيو اميليا التربوية" منهج ريجيو الميليا

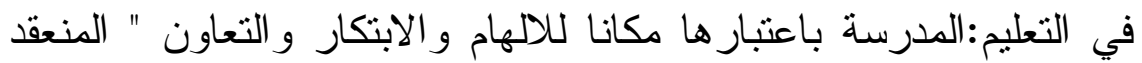


بدولة الكويت مارس VVIV، I والتي أوصت علي ضرورة الاهتمام بتطوير مناهج رياض الأطفال ، وضرورة انتشار منهج ريجيو اميليا

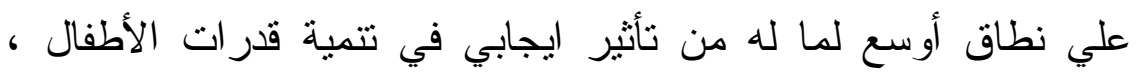
و اكسابهم العديد من المهارات الاجتماعية التي تساعدهم في مواجهة مو اقف الحياة المختلفة.

\section{مشكاة البحث:}

من العرض السابق للدر اسات السابقة واتفاق رؤى المؤتمر ات على أهمية مهار ات التو اصل الاجتماعي لطفل الروضة و الاهتمام بمنهج ريجيو اميليا، تبين وجود نقص لدى الأطفال في مهار ات التواصل الاجتماعي نظر التقبد المعلمة بالطرق التقليدية فى تقديمها لدى أطفال الروضة.

في ضوء ما سبق يمكن تحديد مشكلة الاراسة في التساؤل الرئيس التالي: ما أثز استخدام الأنشطة القائمة علي منهج ريجيو اميليا في تتمية بعض مهار ات التو اصل الاجتماعي لدى طفل الروضة؟

وينبئق من هذا التساؤل الرئيس بعض الأسئلة الفرعية التالية:

1- ما مهار ات التو اصل الاجتماعي المناسبة لطفل الروضة؟ r- ما أهمية تتمية مهار ات التو اصل الاجتماعي لاي طفل الروضة باستخدام

$$
\text { منهج ريجيو اميليا؟ }
$$

r- ما مدي ممارسة طفل الروضة لتلك المهار ات؟ مئك

ع- ما الأنشطة القائمة علي منهج ريجيو اميليا المناسبة لتتمية مهار ات التو اصل الاجتماعي لاي طفل الروضة؟ 
0- ما أثز استخدام منهج ريجيو اميليا في تتمية بعض مهارات التواصل

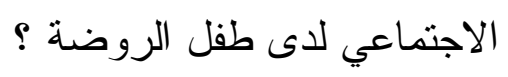

أهداف البحث:

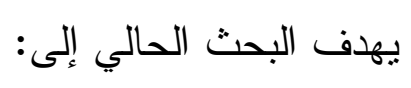

1- تحديد مهار ات التو اصل الاجتماعي المناسبة التى ينبغى تتميتها لدى طفل

$$
\text { الروضة. }
$$

r- تحديد أهمية تلك المهار ات بالنسبة لطفل الروضة.

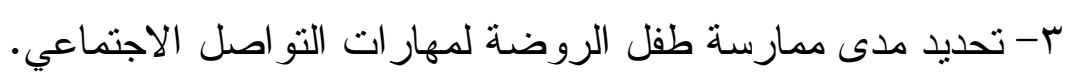

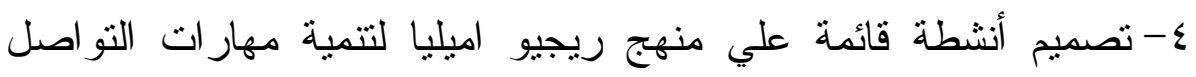

$$
\text { الاجتماعي لدى طفل الروضة. }
$$

ه-قياس أثر استخدام الأنشطة القائمة علي منهج ريجيو الأبليا في نتمية بعض مهار ات التو اصل الاجتماعي لدي طفل الروضة.

\section{أهمية البحث:}

\section{يمكن أن يسهم البحث الحالي فيما يلي:}

1-نوجيه نظر معلمات الروضة إلى أهمية استخدام الأنشطة القائمة على

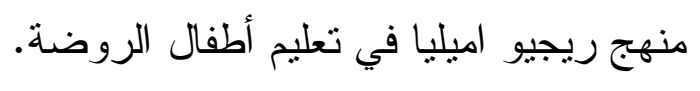

r-توجيه نظر الباحثين إلى أهمية تتمية مهارات التواصل الاجتماعي

$$
\text { المناسبة لطفل الروضة باستخدام منهج ريجيو الميليا . }
$$

r-توجيه نظر الخبراء القائمين على إعداد البرامج لأطفل الروضة

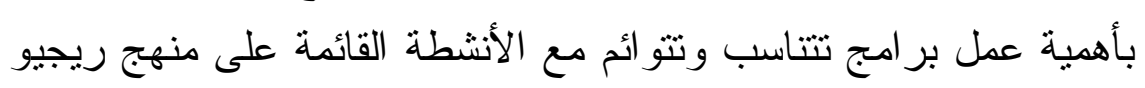
اميليا. 


\section{حدود البحث:}

اقتصر البحث الحالي علي الحدود الاتية: من حيث مهار ات التو اصل الاجتماعي:

اقتصر علي المهار ات التي أجمع المحكمون علي ضرورة تو افرها لدي

$$
\begin{aligned}
& \text { طفل الروضة، وهي: } \\
& \text { 1- المبادرة } \\
& \text { r- الاستئذان } \\
& \text { r- الاتصال الايجابي } \\
& \text { ع - التعاون } \\
& \text { 0- العمل الجماعي } \\
& \text { • من حيث العينة: }
\end{aligned}
$$

اقتصرت الدراسة الحالية علي عينة من أطفال المستوي الثاني (0-7)

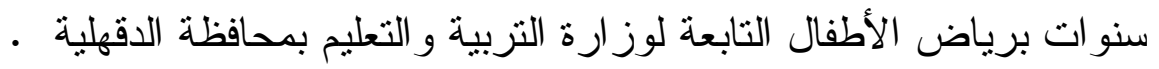

\section{مصطاحاث البحث:}

\section{منهج ريحيو (ميليا:}

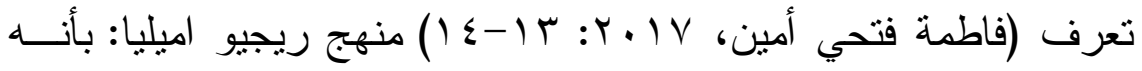
منهج تعليمي يقوم علي عمل الأطفال التعاوني، و المشاركة في مشروعات نابعة من احتياجاتهم ، و التي يتم تحديدها من خلال التو اصل مع المعلمــات و أوليــاء

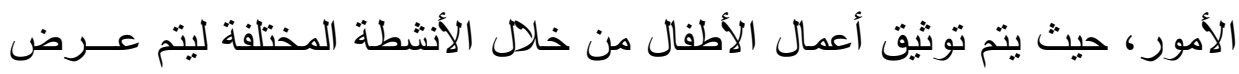
منتجات الأطفال في معرض ختامي للمشروع. 


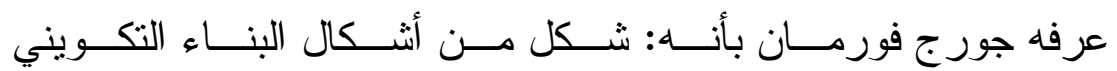

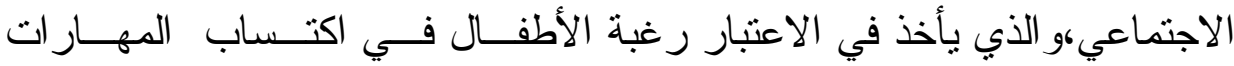
و الخبرات من خلال توفير بيئة تعليمية تعمل علي تشجيعهم على التعبيــر عـن التهن

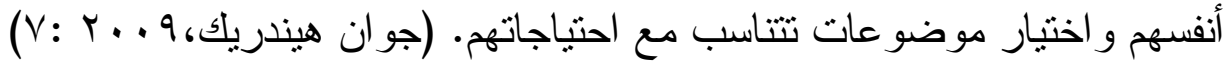

كما انه المنهج الذي يعمل علي ارشاد وتطوير الجوانب العقلية و العاطفية و الاجتماعية و الأخلاقية للأطفال من خلال مشاريع تتو افق مع اهتمامات وميول

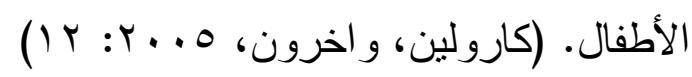

وتعرفه الباحثة اجرائيا : بأنه هو المنهج الذي يحتمد في تكوينه علي

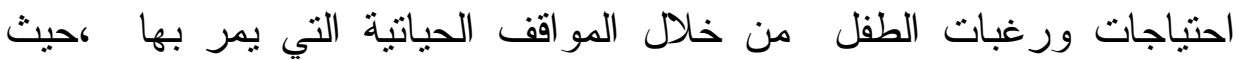

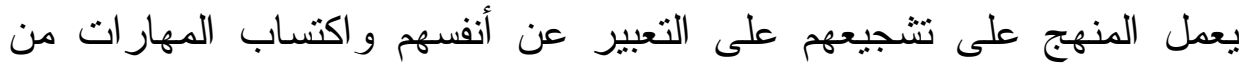
خلال نوفير بيئة غنية تتيح للطفل التفاعل مع أقر انه.

\section{مهارات التواصل الاجتماعي:}

يعرف محمد أبو حلاوة النواصل الاجتماعي بأنه السلوكيات الأساسية المؤثرة في التواصل اللفظي وغير اللفظي التي تصدر عن الطفل أنثاء التفاعل الاجتماعي مع الاخرين في المواقف الاجتماعية المختلفة ـ (سليمان عبدالواحد،

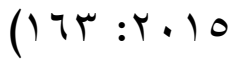

كما عرفها سليمان عبدالواحد بأنها المهار ات الحياتية اللازمة للفرد، و التي

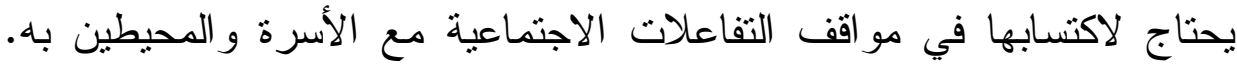

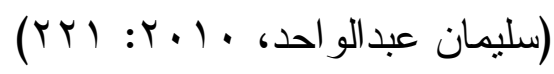

وتعرفها ر انيا محمد (ب. . ب) بأنها قدرة الطفل علي القاء الأسئلة واعطاء المعلومات للاخرين ، و الاستماع الجيد ومدح وثثاء أعمال الاخرين. بان. 
و التواصل هو عملية تبادل بين الأفراد من خلال الحديث أو استخدام لغة

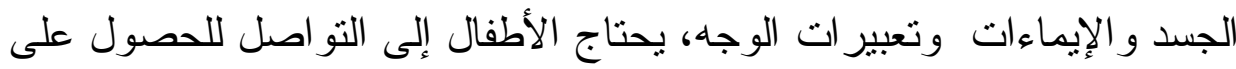

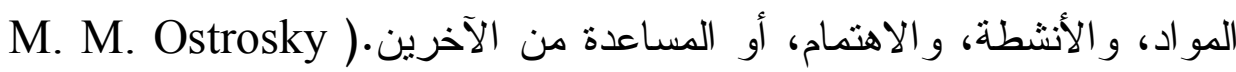

(\&otrers, 2005:2

وتعرف الباحثة مهارات النواصل الاجتماعي اجر ائيا : بأنها المهارات التي تساعد الطفل علي التفاعل الايجابي مع المو اقف الحياتية بثقة، وذللك باتخاذ

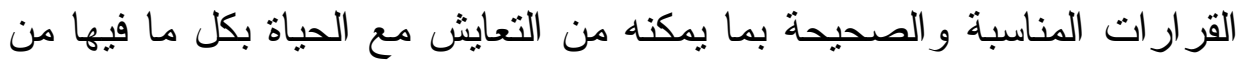

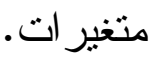

الإطار (لنظري: تم تناول البحث الحالي من خلا المحورين التاليين:

أولا: منهج ريجيو اميليا وتتمل (المبادئ الرئيسية لمنهج ريجيو اميليا ) ثانيا: مهارات التواصل الاجتماعي ، وتتشمل (أساليب التعليم و التعلم المستخدمة لتتمية مهار ات التو اصل الاجتماعياعي).

\section{أولا: منهج ريجيو (ميليا:}

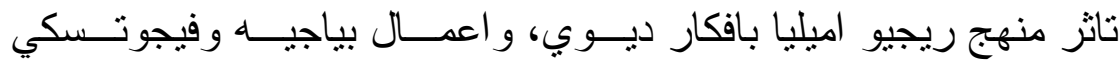

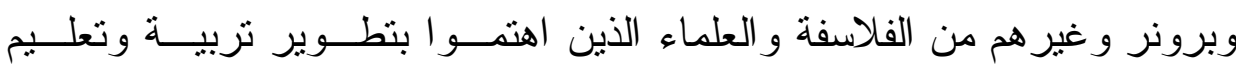

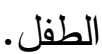

$$
\text { ويعتمد منهج ريجيو اميليا في فلسفته علي ما يلي: }
$$

1. المنهج يتميز بالمرونة ولديه القدرة علي تلبية احتياجات و اهتمامسات الفيات

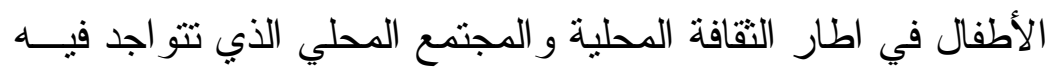

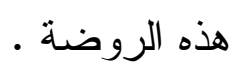


r. استخدام مجموعة صغيرة في تعلم المشاريع و الاستمر ار بين المعلمة

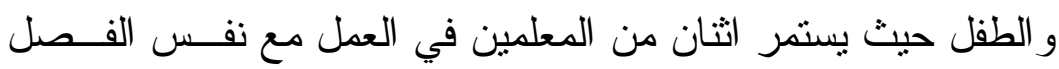

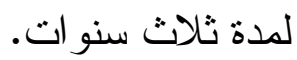

r. توفير الفرص للأطفال للتفاعل مع بعضهم البعض بشكل يومي .

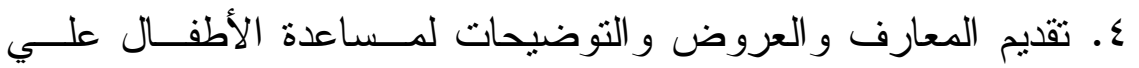

اكتساب المهار ات التي يصعب عليهم معرفتها من تلقاء أنفسهر.

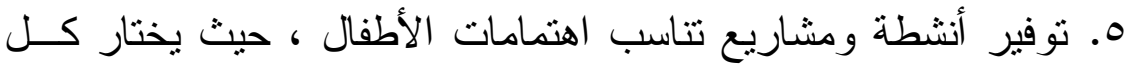

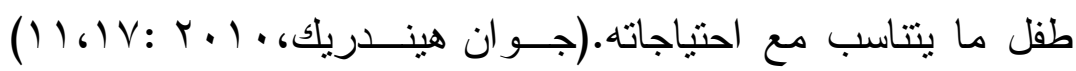

(

المبادئ الرئيسية لمنهج ريجيو (ميليا:

يستند هذا المنهج علي عدة مبادئ:

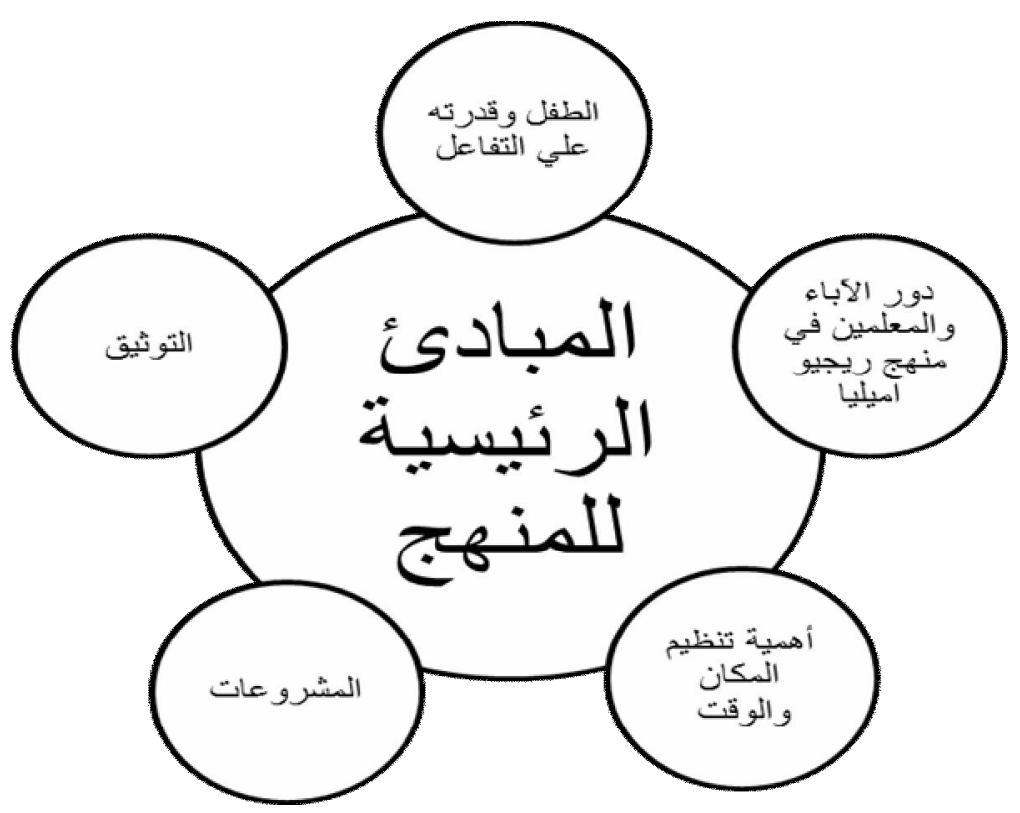

شكل (1) ) : المبادئ الرئيسية لمنهج ريجيو اميليا 


\section{أطقل وقرتها علي التفاعل:}

حيث يدرك المعلمون في ريجيو اميليا اعطاء الاطفال الفرص لتوصيل ما الذي يفكرون به ويعتقدونه الي الاخرين ، فقبل قدرتهم علي القر اءة و الكتابة ينت

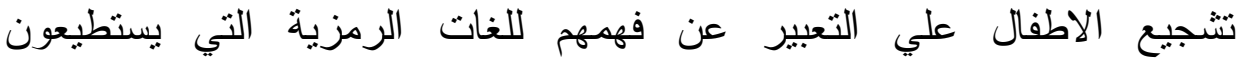
استخدامها، فمن الصفات الأساسية لمنهج ريجيو الميليا هو أنه يسمح للأطفال

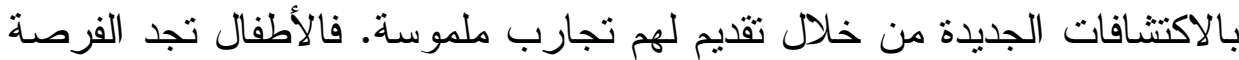

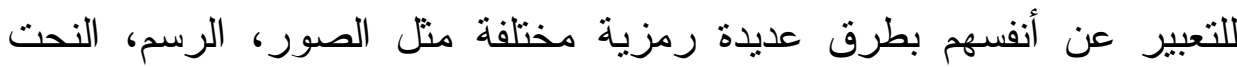
و الألعاب المثيرة. فهذه الرؤية في منهج ريجيو اميليا يطلق عليها"مائة لغة

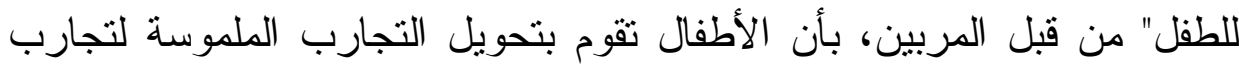
رمزية. ويعمل الأطفال مع أقر انهم حول حل مشاكلهم ويقوم المربين بمساعدتهم خلال هذه الأعمال.(Ayla Arseven,2014:168).

ولذلك ير اعي ضرورة الاهتمام بالطفل الذي يعطينا الاساس لبناء المنهج، فالطفل ينبع من داخله مجموعة من الأفكار والار اء من خلال اختلاطه بالوسط الطيط المحيط ، يعبر عنها بشتي الطرق ليتم استتباط محتوي المنهج له بصورة اعمق الهق

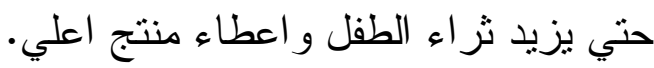
•. دور الاباء و المعلمين في منهج ريجيو اميليا وعلاقتهم بالطقل: مشاركة الو الدين بمثابة قلب نطوير منهج ريجيو ايميليا، وللاباء عدة

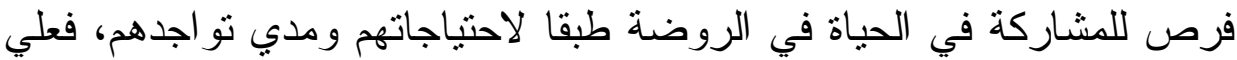
الاباء مسئولية خطيرة تجاه المجتمع باعتبار هما أول مجال تربوي يتو اجد فيه

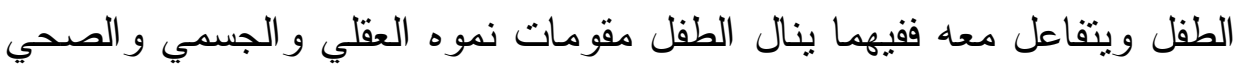

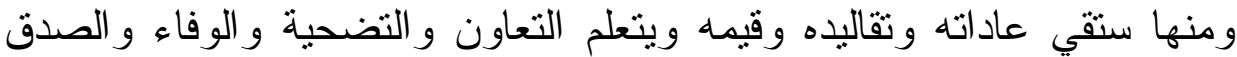
و العطف علي الآخرين و احترامهم وتحمل المسئولية وإثباع حاجاته الأساسية 
كما تبدأ منها أول خطوات الطفل للاتصال بالعالم المحيط به وتكوين الخبرات التي تعينه علي التفاعل مع بيئته المادية و الاجتماعية ومن ثم فالطفل يذهب إلي

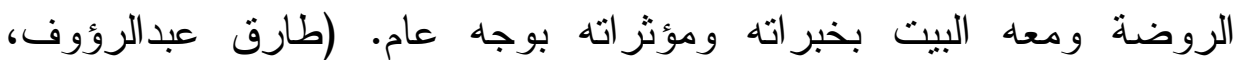

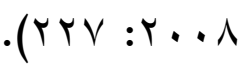

ويتضمن دور المعلم في ريجيو اميليا معرفة كل طفل كفرد وخلق علاقة

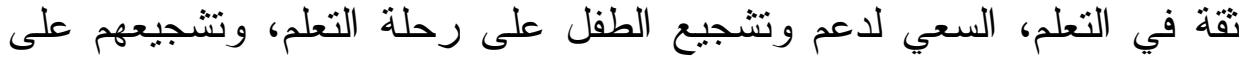

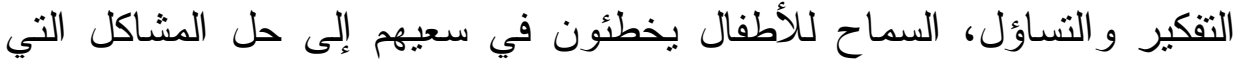
تعتبر أساسية في عملية التعلم، مر اقبة عملية تعلم الطفل قدر الإمكان، فالمعلمين

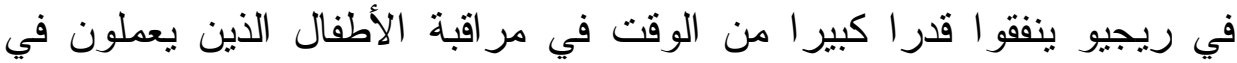

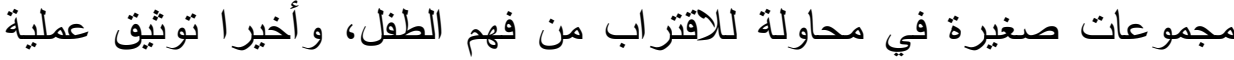

تعلم الطفل. (Marianne Valentine,2006:11)

وفي هذا السياق يمكن توضيح أن التعاون في كل مستويات الروضة هو

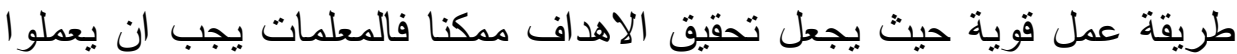
معا كفريق ليس كقائد ومساعد بل اثثان من نفس المستوي، وتحافظ المعلمات علي علاقة قوية مع بعضهم البعض ويندمجوا في نقاثات مستمرة و واظهار

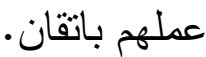

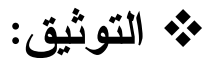

التوثيق هو عبارة عن عمل نسخ من تعليقات الاطفال ومناقثاتهم وصور لنشاطاتهم وتمثيل افكارهم وتعلمه ، من اجل نوثيق العمل وعملية التعلم، و التوثيق في ريجيو اميليا هو العملية الني تتم خلال تعلم الطفل. فانها ليست شيئًا يتم بعد أن يكون الطفل قد انتهى العمل. وهذا له نأثير كبير على دور المعلم ، 
فالمعلم عليه مر اقبة وتوثيق وتحليل رحلات تعلم الأطفال، فهي قادرة على تقديم فرضيات مدروسة حول كيفية توجيه الأطفال في تعلمهم.

و لأن المعلمين في ريجيو يرفضوا التحيز عن أي رأي معين، وبالتالي لابد من ضرورة تبادل الآراء ومناقثة جهات النظر المختلفة، فإنها نستخدم مجموعة متتوعة من الوسائل لإنشاء الوثائق بما في ذلك التسجيلات الصوتية و الفيديو، و الصور ، و الرسومات وكتثابة الملاحظات.

(Marianne Valentine,2006:12)

وتؤكد الباحثة علي أهمية التوثيق كأساس لتطوير العمل مع الأطفال وقياس مدي انجاز الطفل وتقدمه ،و ايضا يعتبر من المعينات التي تساعد الاباء

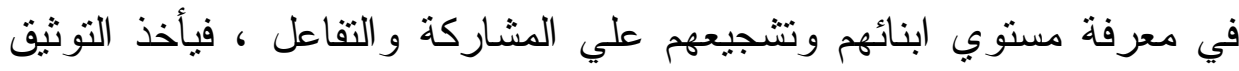

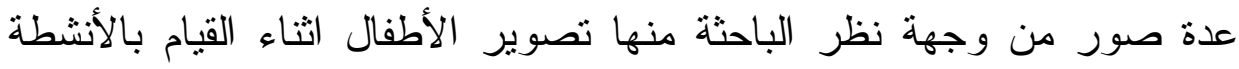

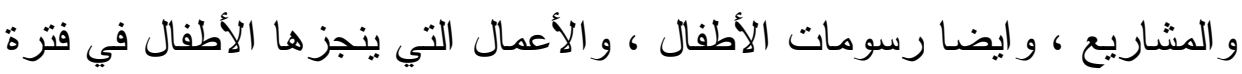
النشاط . و

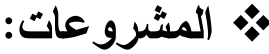

فطريقة المشروعات أحد الأساليب الهامة التي نشأت من مبدأ النشاط بالعمل ،وهذه الطريقة تبني علي نشاط الأطفال في البيئة واختيارهم الحرات الترن لموضوعات يقومون بها تعاونيا حيث يكون لكل طفل دور واضح ومسئولية محددة متقق عليها وحيث يشتركون معا في وضع الخطط و التفكير و العمل

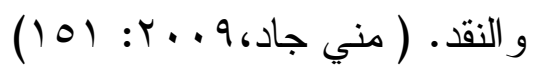

وتزي الباحثة أن المشاريع ممكن ان تبدا من حدث او فكرة او مشكلة يتعرض لها طفل او اثثين او خبرة مكتسبة من المعلم مباشرة ، حيث تنشا افكار 
المشاريع من تجارب الاطفال و المعلمين ومن ممارستهم لبناء المعرفة العامة و المعلمون بسهلو ا اكتشاف الموضوعات الاطفات وللاطفال و العمل علي المشاريع ذات المدي الطويل و القصير، وخبرات الباحثين في ريجيو اميليا نوضح ان النئ الأطفال في مرحلة ما قبل المدرسة يمكنه استخدام وسائل التعبير بالصور و الرموز

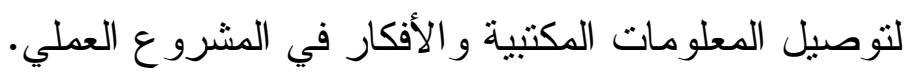

فالمشروع الذي ينم علي أنه نوع من المغامرة و البحث يبدأ من خلال

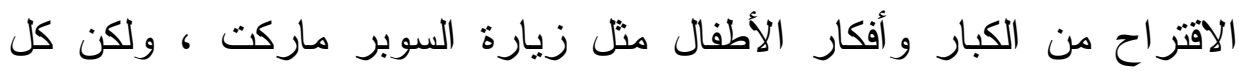

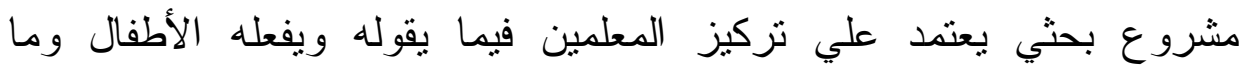

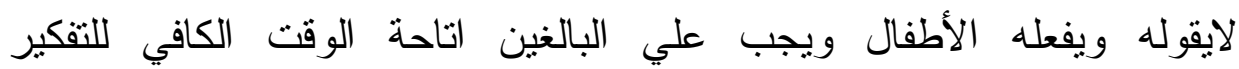

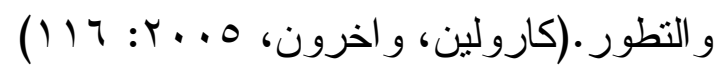

لذا لابد أن يحضر للمشروع وتجهيز الأدوات اللازمة ولكن التحضير له يختلف عن التحضير التقليدي حيث يراعي الهتمامات الأطفال والبحث

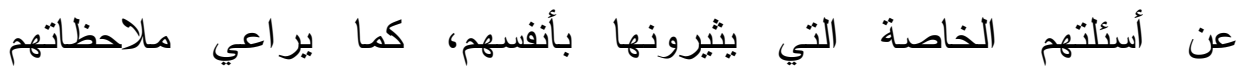

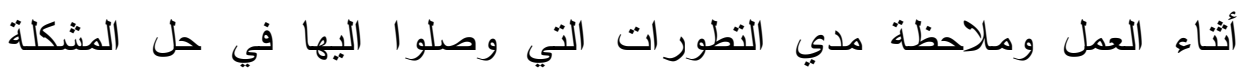

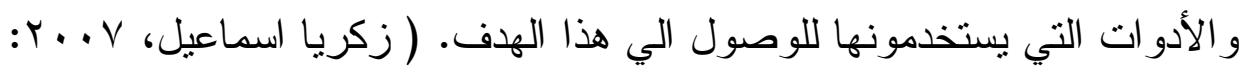

\section{المحور الثانى: مهارات التواصل الاجتماعي}

تعد مهار ات التو اصل الاجتماعي من المهار ات الحاسمة لنجـــاح الطفـلـل

داخل الروضة وتتشمل مهار ات التو اصل، و القدرة علي فهم الاخرين، و التعبيــر

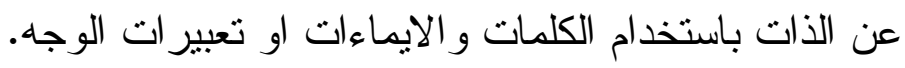

Nicole Gardner-Neblett \& Kathleen Cranley Gallagher, (2013: 1) 
ويمكن توضيح أهمية التو اصل الاجتماعي للطفل حيث يتيح اقامة علاقات

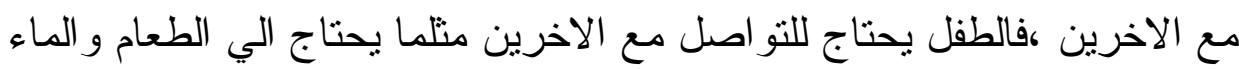

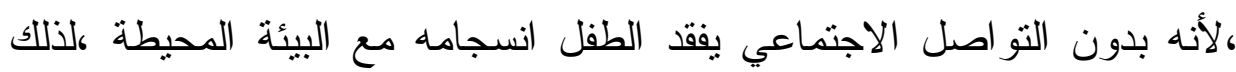

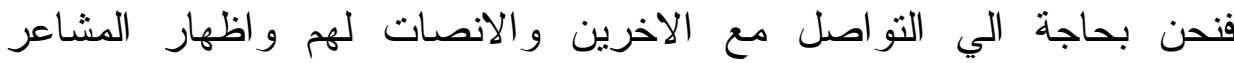

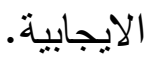

وتكمن أهمية التواصل الاجتماعي باعتبارها واحدة من المهام التتموية

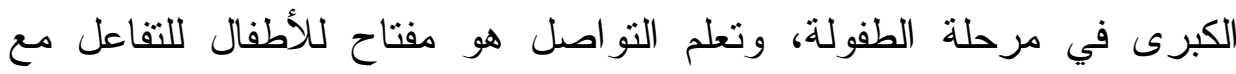

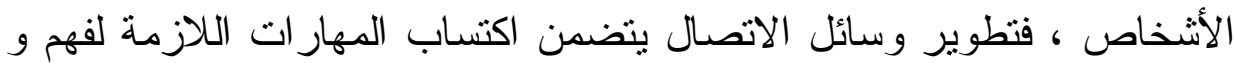
التعبير عن الأفكار و المشاعر و المعلومات (5earns, J.,elc, 2011: فالتو اصل الايجابي الفعال يعطي الطفل الفرصة لتكوين صورته عن ذاته من خلال التواصل الاجتماعي، فالطفل يدرك ذاته من خلال ردود افعال

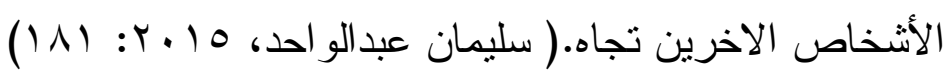

وقد تتاول بعض الباحثين مهارة التواصل الاجتماعي كدر اسة (مي محمد

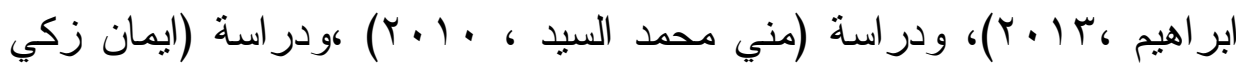

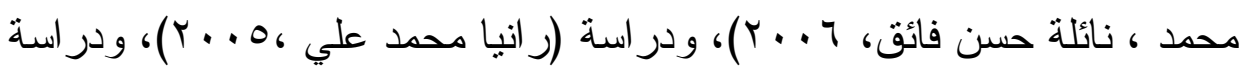

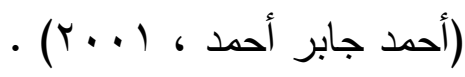

وفي ضوء الدراسات السابقة التي أوصت بتزويد مناهج الطفل بالخبرات

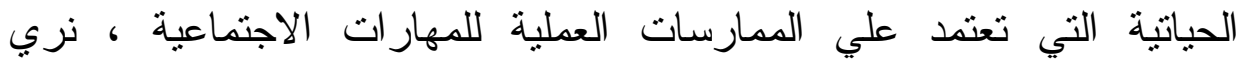
ضرورة تزويد الطفل بالخبرات المناسبة من واقع بيئته الاجتماعية الحقيقية؛ حيث يقتضي تعليم الطفل وتدريبه علي المهار ات الاجتماعية أن يكون هناك تثنابه بين المو اقف التعليمية وبين الحياة الواقعية التي يعايش خبر اتها بصورة يومية، وذللك من خلال توفير مشروعات عملية تتيح للطفل الفرصة 
للتدريب علي كيفية التعامل في المواقف الاجتماعية التي قد يقابلها في بيئته مستقبلا.

أساليب التعليم والتعلم المستخدمة لتنمية مهارات التواصل الاجتماعي: تعددت أساليب التعليم و التعلم المستخدمة لتتمية مهارات التو اصل

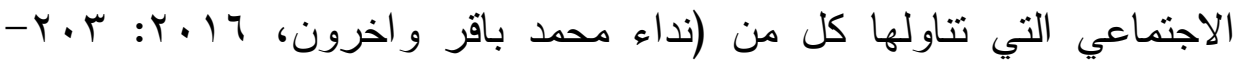
•

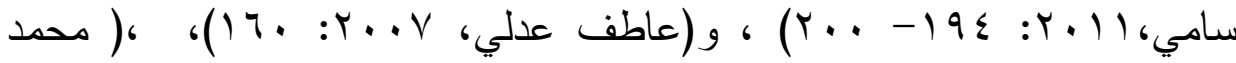

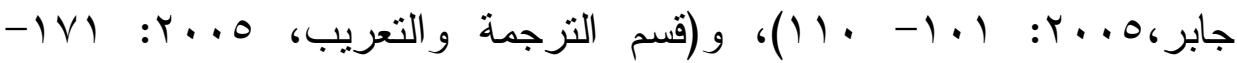

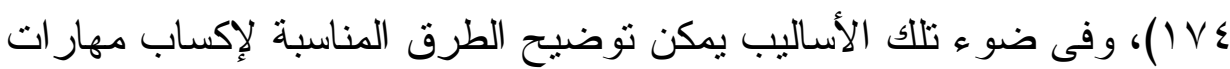
التو اصل الاجتماعي لطفل الروضة و التي تتمثل في الاتي: • القدوة ومتابعة النموذج: تعني القدوة وجود نموذج سلوكي يحاكيه الطفل ويقلده وهذا النموذج قد يكون راه أو قر اه أو سمع عنه فالقدوة من وسائل التربية الفعالة في اكتساب المفاهيم الاجتماعية ، وذلك بارتباطها بتقديم نموذج للسلوك وترجمة الأقو ال الي أفعال ،فالقدوة هي التي تجعل الصور الذهنية للقيم و المبادئ و المفاهيم معروضة عرضا و اقعيا أمام الطفل فينتربها ويقلدها ويحاكيها في سلوكه .

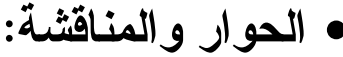

تعرف طريقة المناقشة و الحوار بأنها: حوار شفوي بين المعلم والأطفال يظهر فيها الدور الايجابي الواضح للطفل والتي تتم بصورة طبيعية غير مختلفة تحت اثتر اف المعلم وتتظيمه بهدف تحقيق غايات و أهداف معينة لا بمكن أن تتحقق الا بمشاركة الأطفال. 
وتساعد هذه الطريقة تتمية الجرأة لدي الأطفال وينمي لديهم اللغة

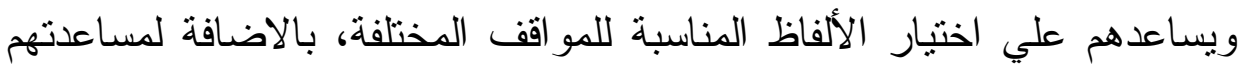

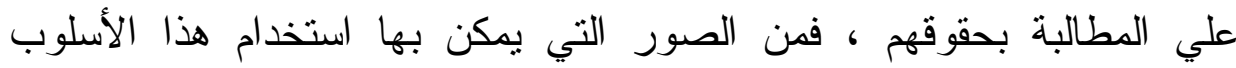

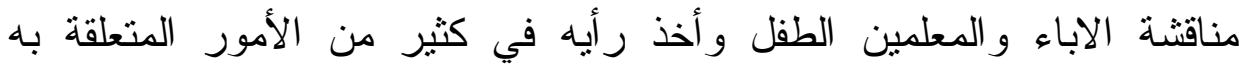

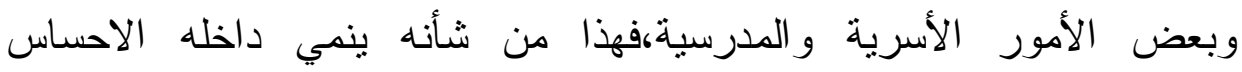
بالمسئولية الاجتماعية وينحه الفرصة لممارسة بعض الأدو ار الاجتماعية.

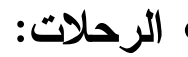

هي جو لات يقوم بها الأطفال خارج الروضة ،وقد تكون تعليمية او غير

ذللك ، فالذي يحدد نوع الرحلة هو الهدف منها.

\section{• القصص والاناثيا والاغاني}

يعد الأسلوب القصصي من الأساليب التربوية المناسبة للأطفال ،ولهذا

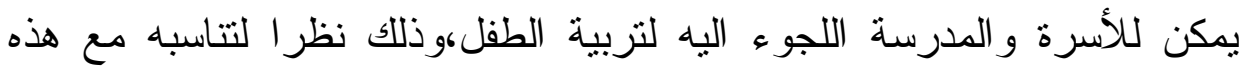

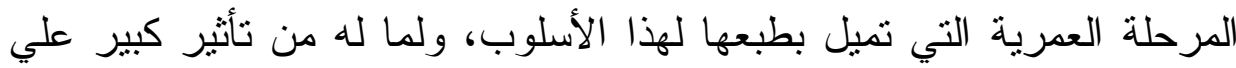

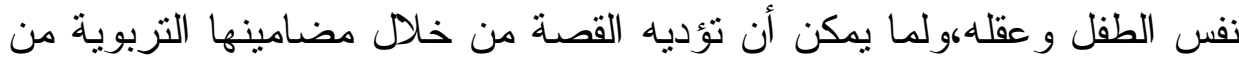

دور في غرس الايمان و القيم و الاتجاهات و الميول المطلوبة في نفس الفرد ـ وبذلك يمد هذا الأسلوب الطفل بالمفاهيم الاجتماعية من خلا أحداث

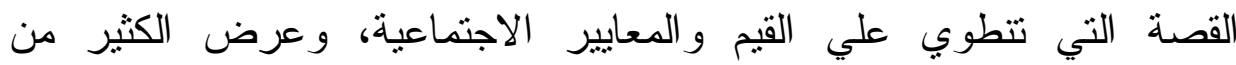

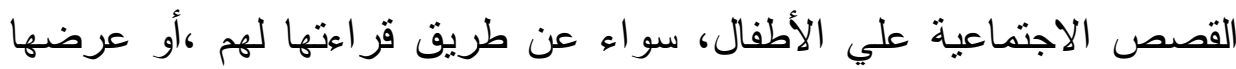

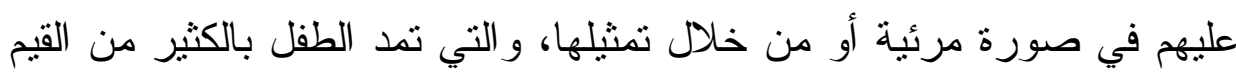
الاجتماعية المرغوبة كالتعاون وتحمل المسئولية والعطف علي المحتاجهوفي نفس الوقت تكسب الطفل الكثير من المعلومات التي تساعده علي التكيف

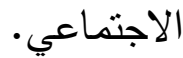


م اللعب و الار اما الاجتماعية:

ان الفكرة الأساسية للألعاب تدور حول جعل المتعلم مشاركا ايجابيا في المواقف التعليمية بحيث يكتسب المفاهيم ويثير التساؤلات ويعمل في فريقه ويصنع الخطط وينفذ القرارات ليصل في النهاية الي حل للمشكلة التي يو اجهها

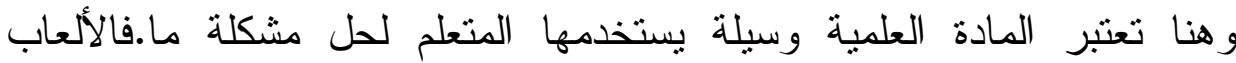
التعليمية ليست أنشطة مسلية تبعث علي التلاميذ المتعة فحسب بل هي لعب

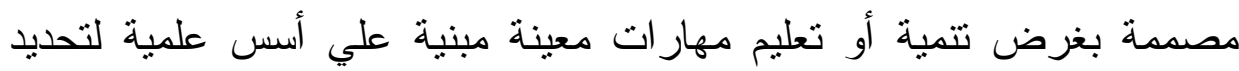

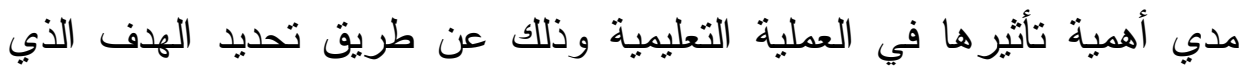

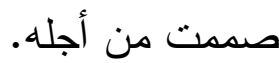

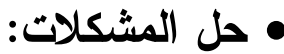

ويتطلب سلوك حل المشكلة من الطفل قيامه بنشاط ومجموعة من الاجر اءات فهو يربط بين خبراته التي سبق تعلمها في مو اقف منتو عة وسابقة،

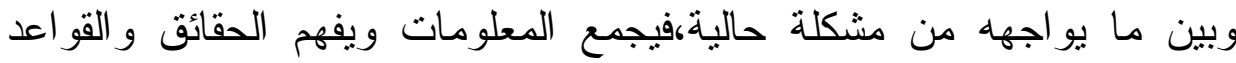
وصو لا الي التعميمات المختلفة .

وتدريب الأطفال علي اسلوب حل المشكلات ينطلب تعريفهم لمشكلات ترتبط بما يتعلمونه من مفاهيم وخبرات مختلفة ،او لمشكلات تتصل بالحياة المدرسية وغير الدرسية داخل بيئاتهم. • التعلم التعاوني: - n

وتتلخص أهية التعلم التعاوني في: أنه ينمي المهارات الاجتماعية كالتعاون، التنظيم، وتحمل المسئولية، وزيادة السلوكيات التي ترتكز علي العمل الجماعي، وينمي القدرة علي تطبيق ما يتعلمه المتعلمون في مواقف جديدة، 
وتتمية الثقدير و العلاقات الثخصية بين الأفراد، وينمي القدرة علي حل المشكلات ومهار ات اتخاذ القر ار .

وتقوم المبادئ الاساسية للتعلم التعاوني علي :مهارة الاتصال وهي ان يتدرب كل فرد علي كيفية التو اصل مع الاخرين و العمل معهم وتتجيع افراد التياديا المجموعة، مما يتطلب زيادة الثقة المتبادلة بين افر اد المجموعة و التعاون و العمل

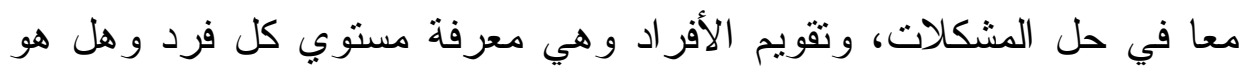

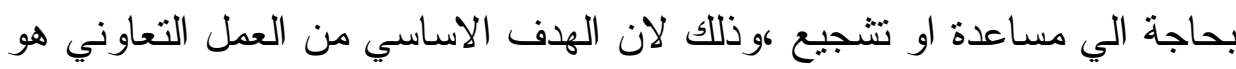

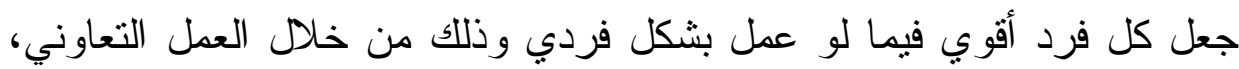

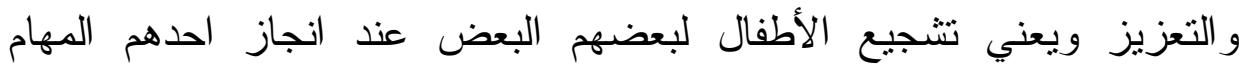

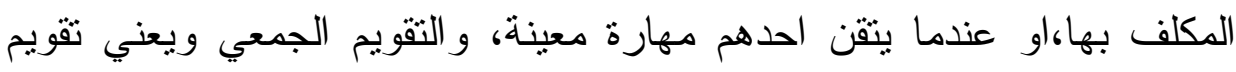

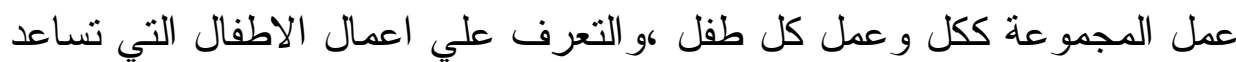
في تحقيق الهدف .

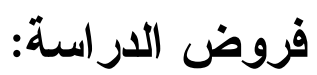
أمكن صياغة فروض البحث الحالي كما يلي: ا-يوجد فرق ذو دلالة إحصائية بين متوسطي درجات أطفال المجمــوعتين

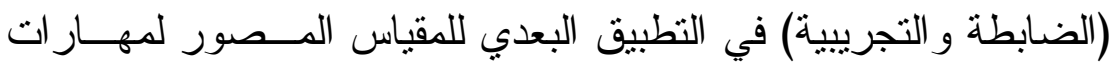
التو اصل الاجتماعي لصالح المجموعة التجريبية.

ץ-يوجد فرق ذو دلالة إحصائية بين متوسطي درجات أطفــال المجموعــة

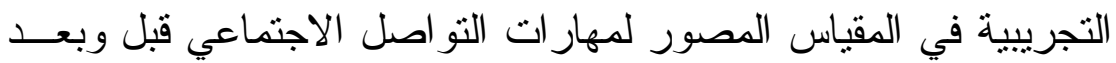
تقديم البرنامج المقتر ح لصالح التطبيق البعدي. 
ب-يوجد فرق ذو دلالة إحصائية بين متوسطي درجات أطفال المجمـو عتين

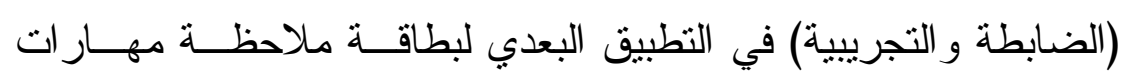

التو اصل الاجتماعي لصالح المجموعة التجريبية.

ع-بوجد فرق ذو دلالة إحصائية بين منوسطي درجات أطفــال المجموعـــة

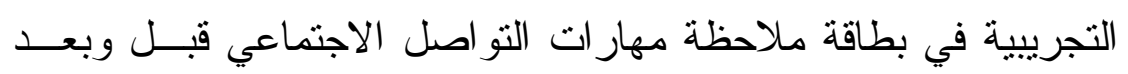
تقديم البرنامج المقترح لصالح التطبيق البعدي.

\section{منهج البحث}

استخدم هذا البحث كلا من:

1- المنهج الوصفي في تحديد الإطار النظري و الدراسات السابقة و إعداد

$$
\text { أدو ات الدر اسة وتحليل وتفسير النتائج. }
$$

r- المنهج التجريبي لاختبار أثز استخدام الأنثطة القائمة علي منهج ريجيو ونئي اميليا (كمتغير مستقل) في تتمية بعض مهار ات التو اصل الاجتماعي

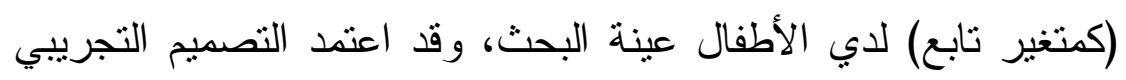
علي مجمو عتين احداهما تجريبية و الأخري ضابطة: 
ويمكن التعبير عن التصميم التجريبى المستخدم في البحث بالشكل التالي :

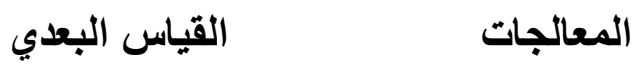

(القياس)

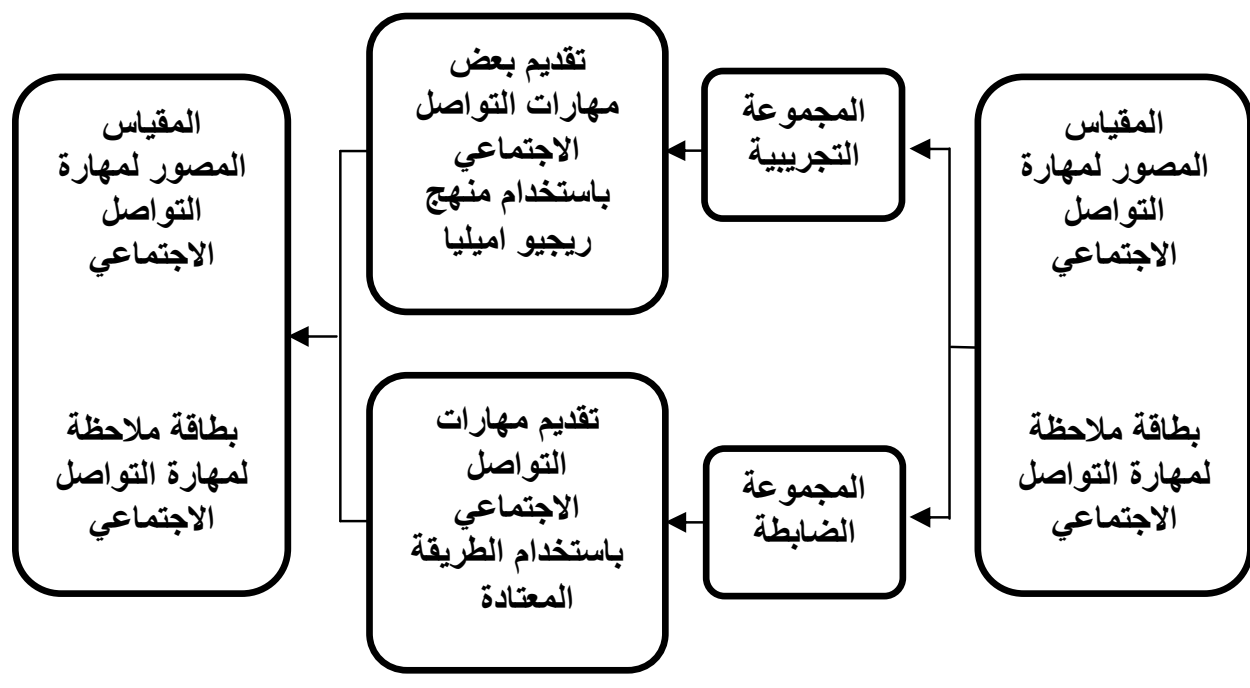

شكل ( r ) : التصميه التجريبى للبحث

\section{متغيرات البحث :}

وقد اشتمل التصميم التجريبي علي المتغيرات التالية:

- المتغير المستقل: منهج ريجيو اميليا.

$$
\text { - المتغير التابع: مهار ات التو اصل الاجتماعي. }
$$

\section{عنه البحث :}

تم اختيار المجموعة التجريبية من أطفال المستوى الثانى لرياض الأطفال (0- 7 سنو ات ) من روضة مدرسة الحرية الابتدائية، و المجموعة الضابطة من أطفال روضة النيل من من

\begin{tabular}{|c|c|}
\hline العدد الثالث : يناير lV. & rTa \\
\hline
\end{tabular}




\section{أدوات البحث:}

1- استبانة لتحديد مهار ات التو اصل الاجتماعي التي يمكن تتميتها لدي طفل

$$
\text { الروضة. (اعداد الباحثة). }
$$

r-مقياس مصور لمهارات التواصل الاجتماعي لأطفال الروضة. (اعداد

$$
\text { الباحثة). }
$$

r-بطاقة ملاحظة مهارات النواصل الاجتماعي لأطفال الروضة. (اعداد

$$
\text { الباحثة). }
$$

وفيما يلي شرح تفصيلي عند اعداد أدوات البحث:

\section{أ - إعداد قائمة مهار ات التواصل الاجتماعي:}

تم إعداد قائمة ببعض مهارات التواصل الاجتماعي التي يمكن تتميتها

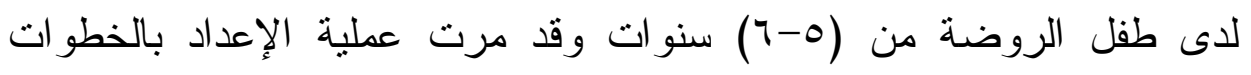

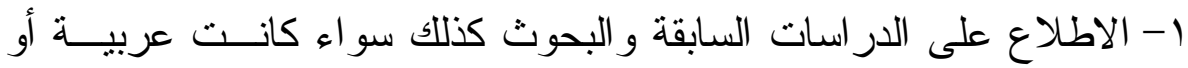

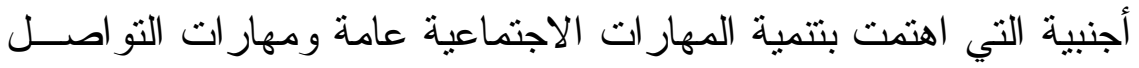

الاجتماعي خاصة كدر اسة (Sani-Bozkurt, 2017)، ودر اســة (Suat

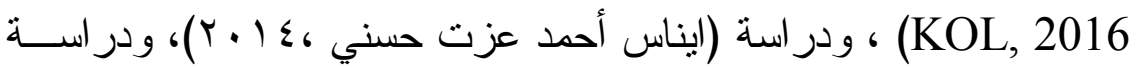

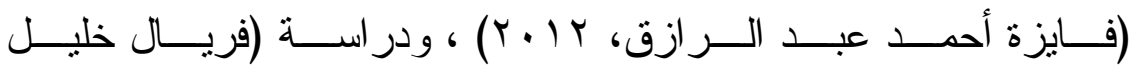

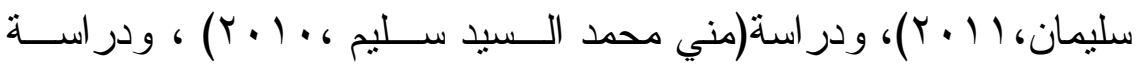

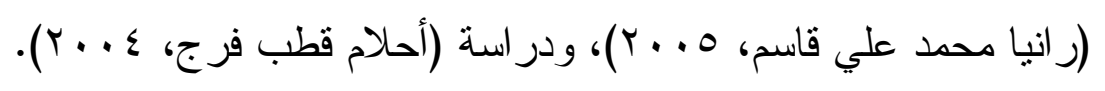

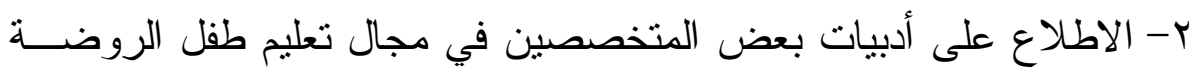

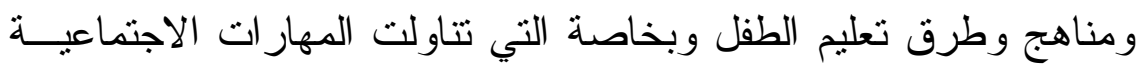




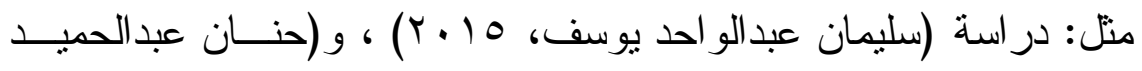

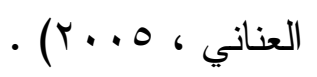

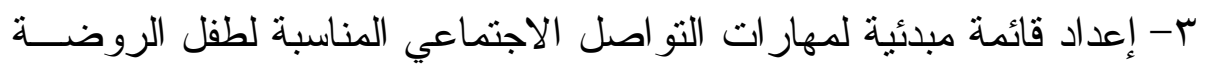

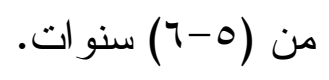

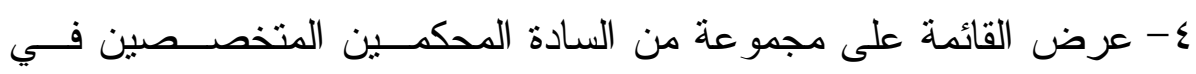

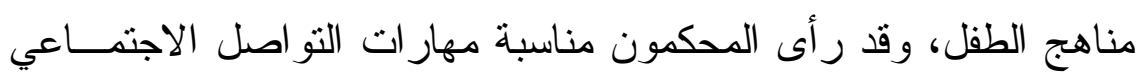

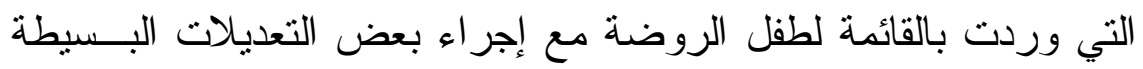

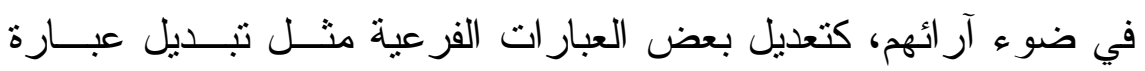

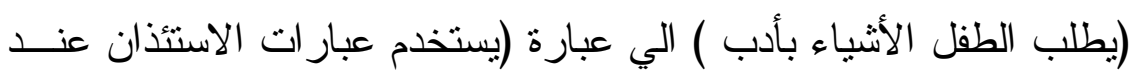

$$
\text { طلب الأشياء ). }
$$

ه- إعداد الصورة النهائية لقائمة مهار ات التو اصل الاجتماعي '.

$$
\text { ب - إعداد مقياس مهار ات التواصل الاجتماعي المصور: }
$$

تم اعداد مقياس لقياس أثنر استخدام الأنثطة القائمة علي منهج ريجيو

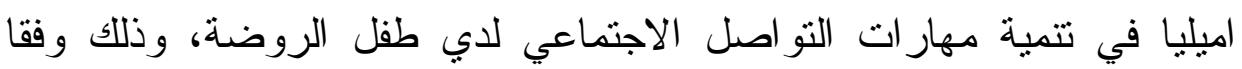
للخطوات التالية:

( ) تحديد الهدف من المقياس

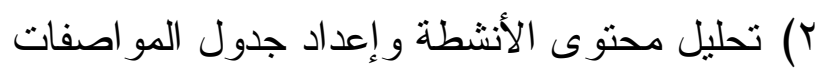
r وتضمنت هذه الخطوة ما يلي: - تحديد عدد المفردات.

1 ملحق ( () استبانة مهار ات النو اصل الاجتماعي لطفل الروضة 


$$
\text { - - تقديد نوع المفردات. - تقدير درجات المقياس. }
$$

وقد أبدى معظم المحكمين مجموعة من الملاحظات يمكن إيجازها فيما يلي:

- ضرورة تغيير بعض البدائل المصورة لعدم وضوح الصورة.

$$
\text { - تغيير بعض البدائل لعدم وضوح ارتباطها بالمفردة وباقي البدائل. }
$$

0) تطبيق المقياس على العينة الاستطلاعية لحساب الثبات وتحديد زمن تطبيق المقياس.

بعد إجراء التعديلات التي رأها السادة المحكمين والتأكد من صدق المقياس قامت الباحثة بإجراء التجربة الاستطلاعية على عينه عددها (Y. ) طفل وطفلة من أطفال المستوى الثانى بروضة مدرسة بدوي بدوي النموذجية، وكان الهدف من إجراء التجربة الاسنطلاعية للمقياس هو: أ - تحديد الزمن اللازم للإجابة على أسئلة المقياس. ب- حساب معامل الثبات للمقياس. وقد قامت الباحثة بالتحقق من تلك الجوانب بالطريقة الأتية: أ- حساب صدق الاتساق الاخلي لمقياس مهار ات التو اصل الاجتماعي: تم استخدام المعادلة الإحصائية المناسبة لحساب معامل الارثباط وقد أسفرت نتائج معاملات الارتباط على أنها جميعا تزاوحت بين (9. (1،، .-

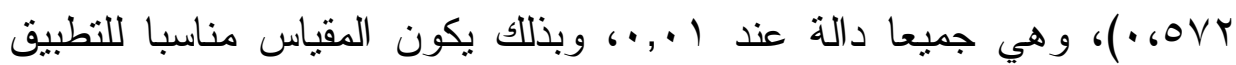
على عينه البحث الأساسية. 


\section{ب - حساب معامل ثبات المقياس}

وقد استخدم البحث التالي طريقة ألفا كرونباخ في حساب معامل الثبات

نظر العمومية هذه الطريقة وصلاحيتها لكل الاختبار ات وبعد قياس معامل ثبات ألفا = (V00, · ) وهي قيمة مقبولة تؤكد درجة اتساق المقياس ج- تحدب الزمن اللازم لتطبيق المقياس

لحساب زمن تطبيق المقياس قامت الباحثة بحساب منوسط الأزمنة التي استغرقها الأطفال في الإجابة على أسئلة المقياس وكان لـ بـ دقيقة. وفى ضوء ما سبق نم وضع مقياس مهارات التو اصل الاجتماعي في

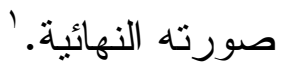

\section{د- اعداد بطاقة ملاحظة مهارات التواصل الاجتماعي:}

تم اعداد بطاقة ملاحظة لقياس أثز استخدام الأنشطة القائمة علي منهج

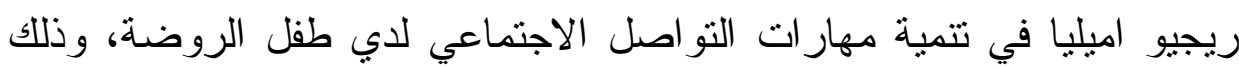

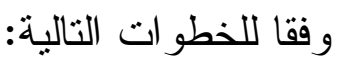

1- تحديد الهدف من بطاقة الملاحظة.

r- ب بياغة مفردات بطاقة الملاحظة.

r- عرض بطاقة الملاحظة في صورتها الأولية على المحكمين. ع- تطبيق بطاقة الملاحظة على العينة الاستطلاعية لحساب الثبات وتحديد

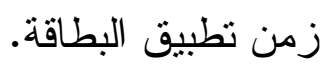

1 ملحق (r) المقياس المصور للمفاهيم لمهار ات التواصل الاجتماعي لطفل الروضة 
بعد إجر اء التعديلات التي رأها السادة المحكمين والتأكد من صدق المقياس قامت الباحثة بإجر اء التجربة الاستطلاعية على عينه عددها (· ب) طفل وطفلة من أطفال المستوى الثانى بروضة مدرسة بدوي بدوي النموذجية، وقد قامت الباحثة بالتحقق من تلاك الجو انب بالطريقة الأتية: ه- حساب صدق الاتساق الداخلي لبطاقة ملاحظة مهارات التواصل

\section{الاجتماعي:}

وقد استخدت الباحثة المعادلة الإحصائية المناسبة لحساب معامل

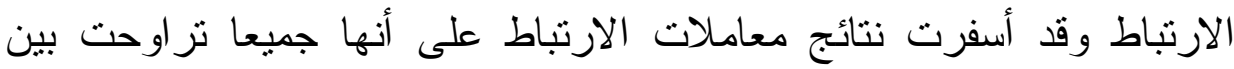

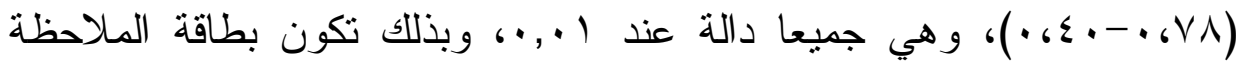
مناسبة للنطبيق على عينه البحث الأساسية.

\section{و - حساب معامل ثبات بطاقة الملاحظة}

وقد استخدم البحث التالي طريقة ألفا كرونباخ في حساب معامل الثبات

نظر العمومية هذه الطريقة وصلاحيتها لكل الاختبار ات وبعد قياس معامل ثبات

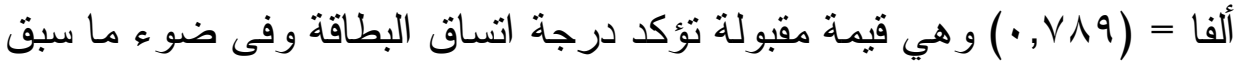
تم وضع بطاقة ملاحظة مهارات التواصل الاجتماعي المصور في صورتها

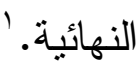

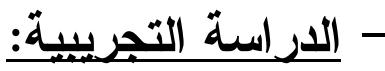
أ- التصميم التجريبي

يهذف البحث الحالي إلى تتمية بعض مهارات التواصل الاجتماعي

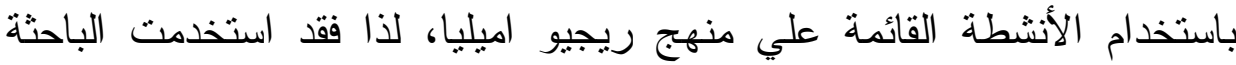
1 ملحق (ॅ) بطاقة ملاحظة مهارات التو اصل الاجتماعي لطفل الروضة 
تصميم المجموعتين التجرييية و الضابطة ذات القياسين القبلي و البعدي، و هذا

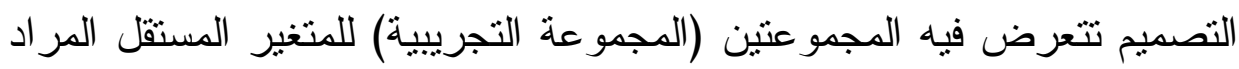

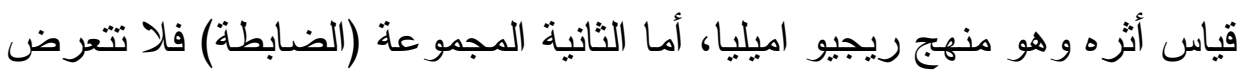

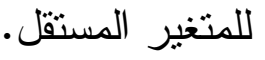

وقد ثم اختبار هذا التصميم التجريبي للهجموعتين لقياس أثر استخدام

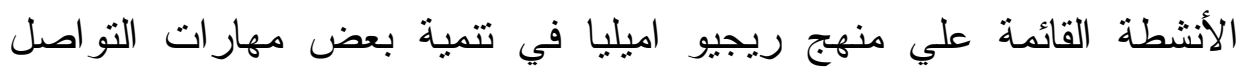
الاجتماعي لطفل الروضة، حيث تم اختيار عينه البحث وتقسيمها لعينه ضابطة وعينة تجريبية و النطبيق القبلي لأدوات البحث (المقياس المصور ) ثم تطبيق الأنشطة باستخدام منهج ريجيو اميليا على المجموعة التجريبية فقط ثم تطبيق أدوات البحث بعديا على المجمو عتين (الضابطة و التجريبية). ب - ت تحديد عينه البحث تم اختيار عينه البحث من أطفال المستوى الثانى من (-7-7) سنوات من

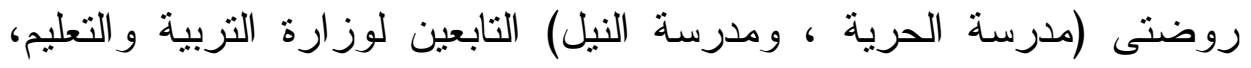

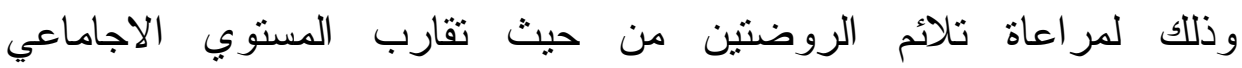

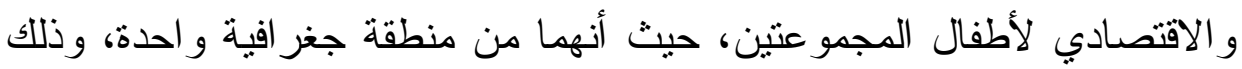

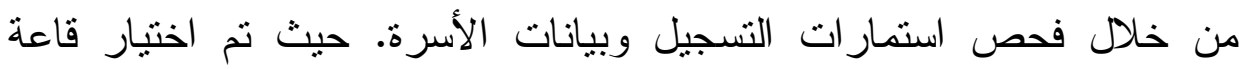

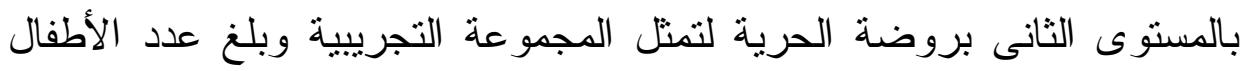

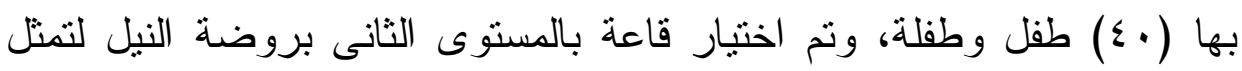

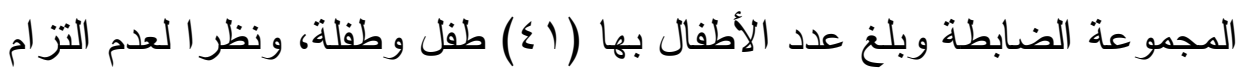

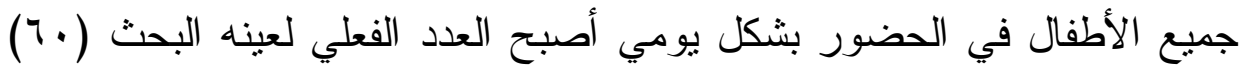
طفل وطفلة موزعين علي النحو التالي: 
جدول (1)

وصف عينة البحث

\begin{tabular}{|c|c|c|}
\hline اسم الروضة & عدد الأطفال & المجموعة \\
\hline الحرية & $r$. & المجمو عة التجريبية \\
\hline النيل & $r$. & النجمو عة الضابطة \\
\hline \multicolumn{2}{|c|}{. ז طفلا } & المجمو ع الكلى \\
\hline
\end{tabular}

\section{ج -إجراءات تنفيذ البحث}

بعد إعداد أدوات البحث و التأكد من صدقها وثناتها وصلاحيتها للتطبيق الميداني، وبعد تحديد الإجراءات التجريبية اللازمة لتتفيذ تجربة البحث، و المتمنلة في تحديد التصميم التجريبي، واختيار عينه البحث، فقد قامت الباحثة التئة بإنباع الخطو ات التالية لتنفيذ البحث: أولا: إجراعات قبل تطبيق الأشطة

$$
\text { التطبيق القبلي لأدوات البحث }
$$

تم تطبيق مقياس مهار ات التواصل الاجتماعي المصور على عينة البحث

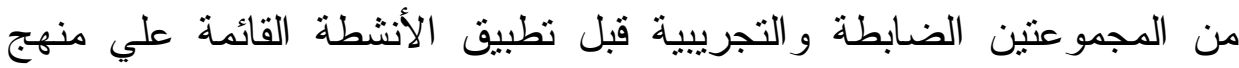
ريجيو اميليا مباشرة؛ وذلك للتأكد من تكافؤ المجموعنين حيث نم حساب

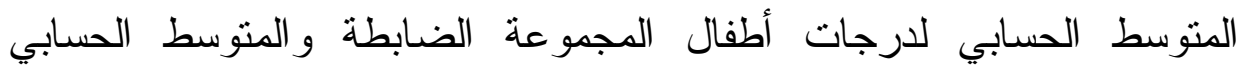

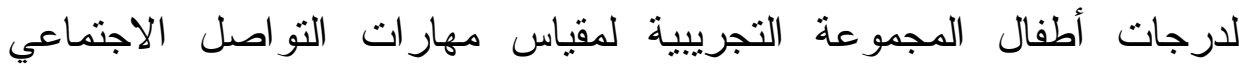
المصور، ونم استخدام اختبار " ت " لحساب الفرق بين منوسطي درجات مجمو عتين مستقلتين وتم التوصل إلى النتائج الموضحة بالجدول الاتي: 
جدول (r)

دلالة الفروق بين متوسطي درجات المجموعتين الضابطة والتجريبية في التطبيق القبلي لمقياس مهارات التو اصل الاجتماعي

\begin{tabular}{|c|c|c|c|c|c|c|c|c|}
\hline \multirow{3}{*}{ مستوى الدلالة } & \multirow{3}{*}{ الللالة } & \multirow{3}{*}{ ت } & \multirow{3}{*}{ الدرجات } & \multicolumn{4}{|c|}{ المجموعة } & \multirow{3}{*}{ مقارات الاجتواصل } \\
\hline & & & & \multicolumn{2}{|c|}{ التجريبية } & \multicolumn{2}{|c|}{ الضابطة } & \\
\hline & & & & معياري & متوسط & انعياري & متوسط & \\
\hline غنير دال & I & 9 & 01 & $r, 19$ & $9,7 \pi$ & $1,0 \mathrm{~V}$ & $q, \Sigma \vee$ & \\
\hline
\end{tabular}

يتضح من الجدول السابق أن قيمة (ت) في التطبيق القبلي لدقياس مهار ات التواصل الاجتماعي غير دالة احصائيا، مما يدل علي أنه لا يوجد فروق بين متوسطي درجات أطفال كل من المجموعنين التجريبية و الضابطة، وهذا يشير إلى تكافؤ المجموعتين التجريبية والضابطة قبل تطبيق الأنشطة

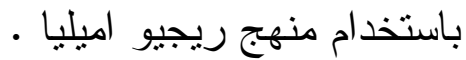
تنظيم قاعة النشاط لإجراء التطبيق: تم تجهيز قاعة النشاط بالأدوات المناسبة لقله الأدوات اللازمة لإجراء الأنشطة وفقا للخطو ات التالية: - اعداد الوسائل التعليمية في ضوء الأشياء المألوفة في بيئة الطفل و التي يتعرض لها في المواقف الحياتية ، وتتوعت الوسائل المستخدمة لتشمل التياه الأثياء الحقيقة و المجسمات مثل : السمك، الطوب الأحمر ، الذرة ، النقود 
الورقية و المعدنية، مجسم للسوبر ماركت ،البيتز ا وايضا استخدام الصور

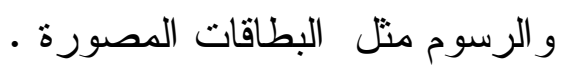

- نم استخدام طريقة المشروعات في تقديم الأنشطة المقدمة للطفل ، حيث

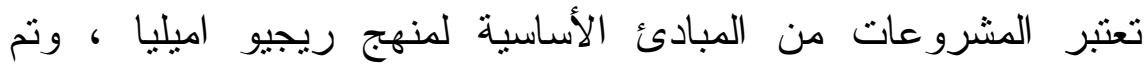

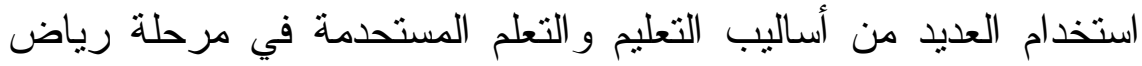

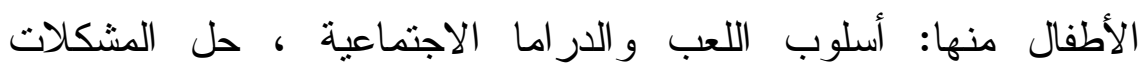

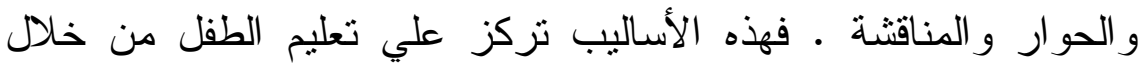

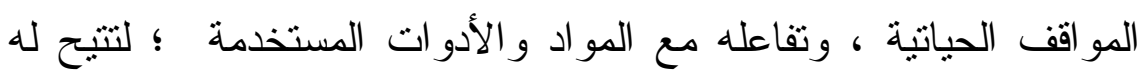

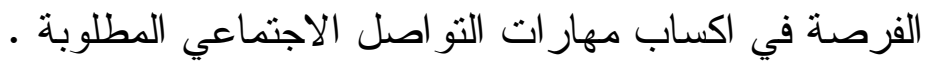

- تغيير موضع الكراسي والطاولات حسب طبيعة كل نشاط فاذا كانت الأنشطة ذات طابع تعاوني يستدعى تقسيم الأطفال لمجموعات صغيرة؛

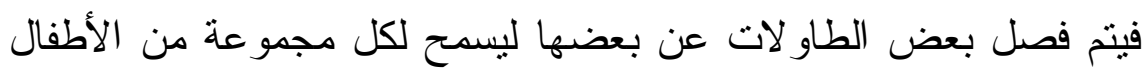

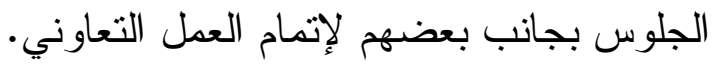

- إعداد مجموعة من المكافئات الإثابة للأطفال لتتجيعهم على التعاون

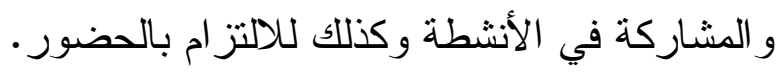

\section{ثانيا: إجراءات تطيق الأشطة القائمة علي منهج ريجيو اميليا المقترحة}

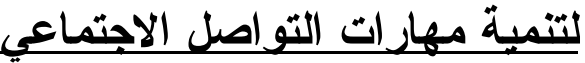

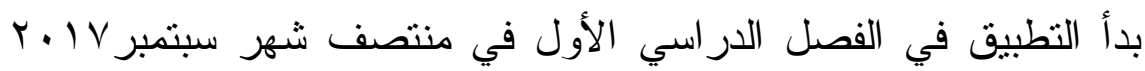

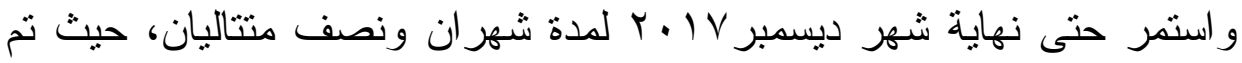
تطبيق الأنشطة القائمة علي منهج ريجيو اميليا لتعليم أطفال المجموعة التجريبية

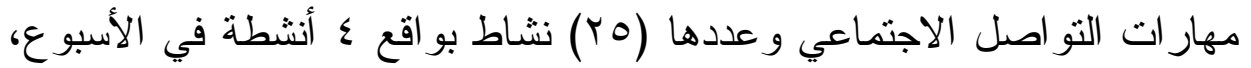

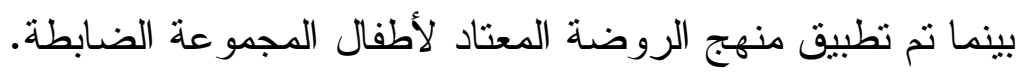

المجلد الثالث


ملاحظات أثناء التطبيق :

أثناء تطبيق الأنشطة القائمة علي منهج ريجيو اميليا المقترحة لتمية بعض مهار ات التو اصل الاجتماعي ظهرت العديد من الملاحظات على أطفال المجموعة التجريبية على النحو التالى : لإسي

- المشاركة الفعالة للأطفال فى اداء الأنشطة المقدمة في صورة مشاريع ،

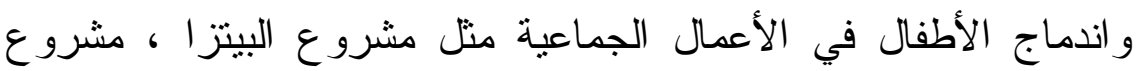
السمك، ور غبة الأطفال فى المشاركة فى مجمو عات العمل. - تساؤل معلمات الروضة حول كيفية اعداد الأنشطة القائمة علي منهج ريجيو اميليا ،وطلب عمل دورة تدريبية مبسطة للمعلمات مع دعمهر بالأمنثة. - ابداء أولياء الأمور لرغبتهم فى التفاعل والحضور مع أطفالهم أثناء التطبيق، وحرصهم علي تصوير الأنشطة و الأعمال التي قام بها الأطفال

$$
\begin{aligned}
& \text { التى تم عرضها فى المعرض الختامي. } \\
& \text { ثالثا: التطبيث البعدي لأدوات البحث }
\end{aligned}
$$

بعد الانتهاء من تطبيق الأنشطة القائمة على منهج ريجيو اميليا لتنمىة

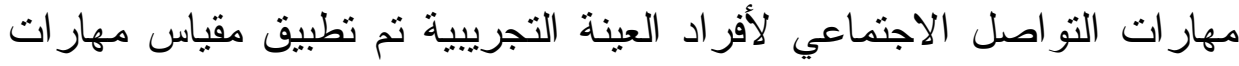

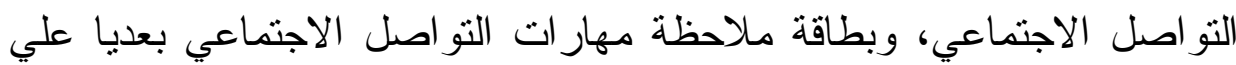
كل من المجمو عتين الضابطة و التجريبية بصورة فردية.

$$
\text { نتائج البحث وتفسيرها: }
$$

يتم عرض النتائج الخاصة بتطبيق كل من مقياس مهار ات التو اصل الاجتماعي ، وبطاقة ملاحظة مهار ات التواصل الاجتماعي علي عينة البحث

$$
\text { وتحليل هذه النتائج و تقسير ها في ضوء وفروض البحث، كالاتي: }
$$




\section{اختبار الفرض الأول}

ينص الفرض الأول على أنه " يوجد فرق ذو دلالة إحصائية عند مستوي

(0., •) بين متوسطي درجات أطفال المجموعة التجريبية في التطبيقين (القبلي و البعدي) للمقياس المصور لمهار ات التو اصل الاجتماعي لصالح التطبيق

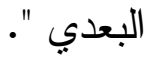

و لاختبار الفرض الأول تم استخدام اختبار "ت" للمجموعة التجريبية لبحث دلالة الفروق بين متوسطي القياسين القبلي و البعدي للمجموعة التجريبية في مقياس مهار ات التو اصل الاجتماعي المصور ، ويوضح جدول (Y) تلك النتائج جدول (r)

دلاحة الفروق بين متوسطي درجات المجموعة التجريبية في كل من القياسين

\begin{tabular}{|c|c|c|c|c|c|c|c|c|c|c|}
\hline \multirow{3}{*}{ الاثر } & \multirow{3}{*}{$\square 2$} & \multirow{3}{*}{ مستوى } & \multirow{3}{*}{ الللالة } & \multirow{3}{*}{ ت } & \multirow{3}{*}{ الحرجية } & \multicolumn{4}{|c|}{ المجموعة } & \multirow{3}{*}{ التهارات } \\
\hline & & & & & & \multicolumn{2}{|c|}{ التجريبية بعدى } & \multicolumn{2}{|c|}{ التجريبية قبلي } & \\
\hline & & & & & & انعياري & متوسط & معياري & متوسط & \\
\hline كبير & . $6 V$ & دال ع.. & $\ldots$ & $9 . \mathrm{VT}$ & rq & 1.04 & Ir.VT & r.19 & T.79 & \\
\hline
\end{tabular}

ويتضح من الجدول السابق وجود فرق ذو دلالة إحصائية بين متوسطي

درجات التطبيقين القبلي و البعدي لعينه البحث ، حيث جاءت قيم "ت" أكبر من القيمة الجدولية عند مستوى (1 +, +) ودرجات حرية (Yq) مما يعنى حدوث نمو في اكتساب مهار ات التو اصل الاجتماعي لدى عينه البحث مما يدل على فاعلية الأنشطة القائمة علي منهج ريجيو اميليا في تتمية مهار ات التواصل الاجتماعي، ولقياس على فاعلية الأنشطة القائمة علي منهج ريجيو امليا في تتمية مهار ات 
التو اصل الاجتماعي تم استخدام اختبار (ロ2 ) لتحديد حجم تأثثر الأنثطة القائمة علي منهج ريجيو اميليا في مهارات التواصل الاجتماعي بالمقياس و الدرجة

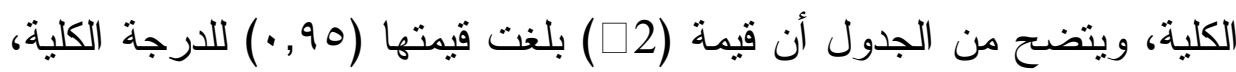

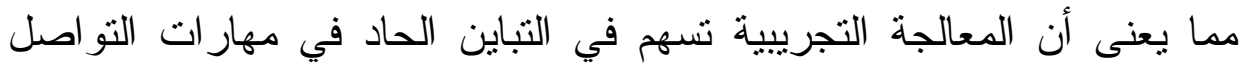
الاجتماعي لدى عينه البحث. اختبار الفرض الثانى الأيه

ينص الفرض الثاني على أنه " يوجد فرق ذو دلالة إحصائية عند مسنوي دلالة ه.,. بين متوسطي درجات أطفال المجمو عتين (الضابطة و التجريبية)

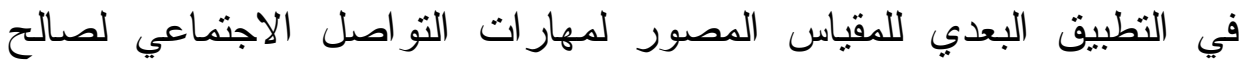
المجموعة التجرييية ". تم استخدام اختبار " ت" لمجموعتين غير مرتبطنين؛ لبحث دلالة الفرق بين متوسطي درجات كل من المجموعة التجريبية والمجموعة الضابطة في مهار ات التواصل الاجتماعي للمقياس المصور و الدرجة الكلية بعدياً، والجدول

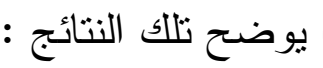

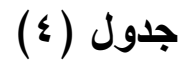

دلالة الفروق بين متوسطي درجات كل من المجموعتين (التجريبية والضابطة)

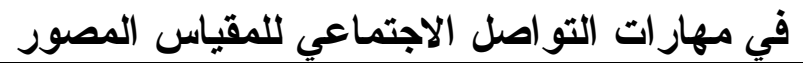

\begin{tabular}{|c|c|c|c|c|c|c|c|c|}
\hline \multirow{3}{*}{ مستوى اللدلالة } & \multirow{3}{*}{ اللالالة } & \multirow{3}{*}{ ت } & \multirow{3}{*}{ الدرجية } & \multicolumn{4}{|c|}{ المجموعة } & \multirow{3}{*}{ الاجتماعي } \\
\hline & & & & \multicolumn{2}{|c|}{ الضابطة } & \multicolumn{2}{|c|}{ التجريبية } & \\
\hline & & & & معياري & متوسط & معياري & متوسط & \\
\hline دال عند & $\ldots$ & 9,94 & 01 & $1, V Y$ & $9,0 \mathrm{~V}$ & $1,0 r$ & $I r, V r$ & \\
\hline
\end{tabular}


يتضح من الجدول السابق وجود فرق ذو دلالة إحصائية بين منوسطي

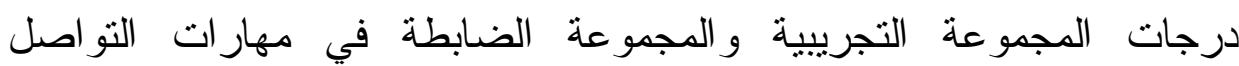
الاجتماعي المتضمنة بالمقياس المصور ؛ حيث جاءت قيمة " ت" أكبر من القيمة

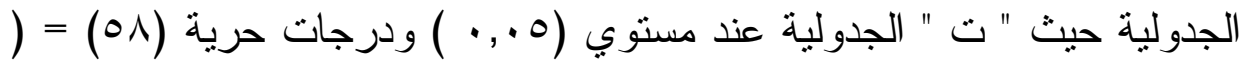

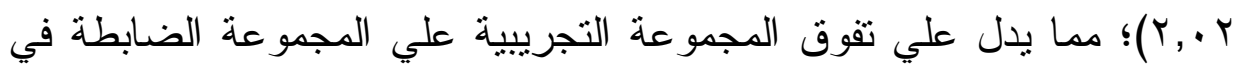
مهارات التواصل الاجتماعي للمقياس المصور؛ مما يدل فعالية المعالجة التجريبية من أثر استخدام أنشطة منهج ريجيو اميليا في تتمية مهارات التواصل

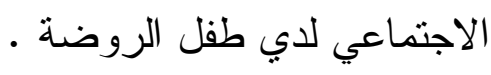
اختبار الفرض الثالث

ينص الفرض الثالث على أنه " يوجد فرق ذو دلالة إحصائية عند مسنوي دلالة ه.,. بين متوسطي درجات أطفال المجمو عتين (الضابطة و التجريبية) في التطبيق البعدي لبطاقة ملاحظة مهار لت اتل التواصل الاجتماعي لصالح

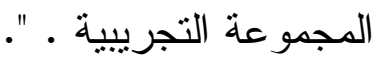
تم استخدام اختبار " ت" لمجموعتين غير مرتبطتين؛ لبحث دلالة الفرق بين متوسطي درجات كل من المجموعة التجرييية والمجموعة الضابطة في

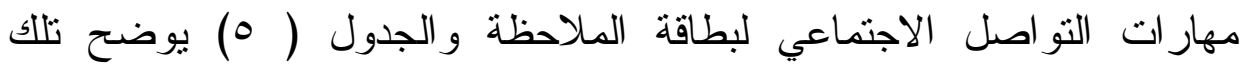

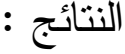




\section{جدول (•)}

دلالة الفروق بين متوسطي درجات كل من المجموعتين (التجريبية و الضابطة) في مهارات التواصل الاجتماعى لبطاقة الملاحظة

\begin{tabular}{|c|c|c|c|c|c|c|c|c|}
\hline \multirow{3}{*}{ مستلالة } & \multirow[b]{3}{*}{ الللالة } & \multirow[b]{3}{*}{ ت } & \multirow{3}{*}{ الحرجية } & \multicolumn{4}{|c|}{ الججموعة } & \multirow{3}{*}{ 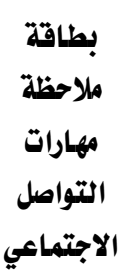 } \\
\hline & & & & \multicolumn{2}{|c|}{ الضابطة } & \multicolumn{2}{|c|}{ التجريبية } & \\
\hline & & & & انحياري & متوسط & انحياري & متوسط & \\
\hline دال عند & “. & Tr.r & $0 \wedge$ & $1, \varepsilon 1$ & 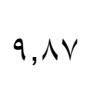 & 1,or & $\mid r, \lambda V$ & \\
\hline
\end{tabular}

يتضح من الجدول السابق وجود فرق ذو دلالة إحصائية بين متوسطي

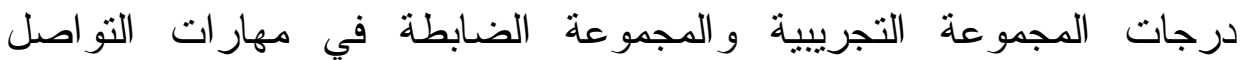
الاجنماعي المتضمنة ببطاقة الملاحظة ؛ حيث جاءت قيمة " ته " أكبر من القيمة

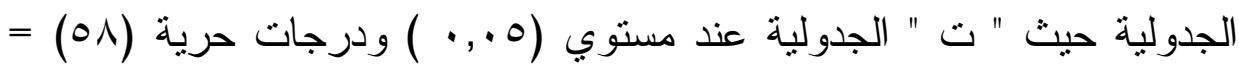

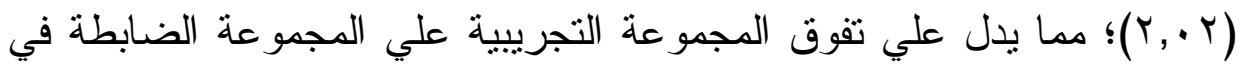

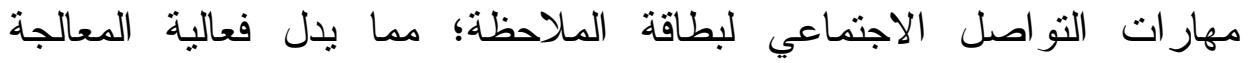

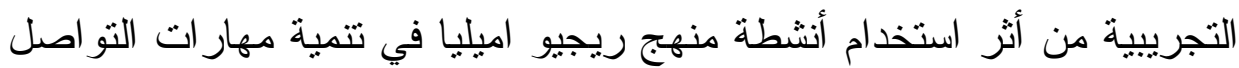

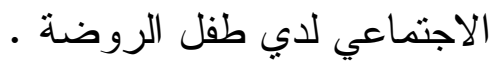

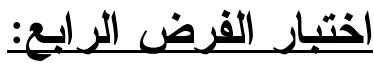

ينص الفرض الرابع على أنه " يوجد فرق ذو دلالة إحصائية بين

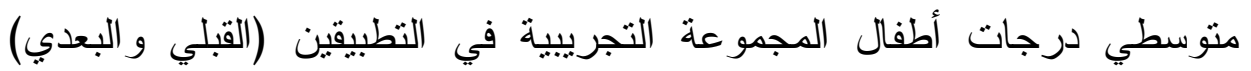
لبطاقة ملاحظة السلوكيات الاجتماعية لصالح التطبيق البعدي. ".

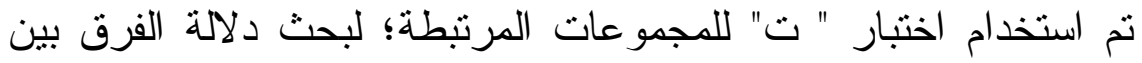

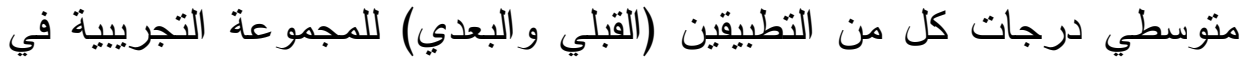

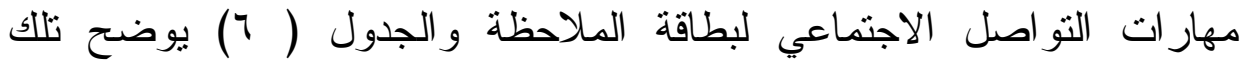

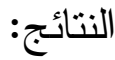


جدول (7)

دلالة الفروق بين متوسطي درجات كل من التطبيقين (القبلي والبعدي)

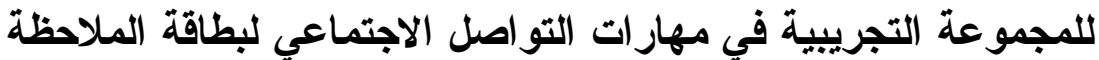

\begin{tabular}{|c|c|c|c|c|c|c|c|c|}
\hline \multirow{3}{*}{ مستول } & \multirow{3}{*}{ اللالة } & \multirow{3}{*}{ ت } & \multirow{3}{*}{ العربية } & \multicolumn{4}{|c|}{ المجموعة } & \multirow{3}{*}{ ملامهارة } \\
\hline & & & & \multicolumn{2}{|c|}{ التجريبية بعدي } & \multicolumn{2}{|c|}{ التجريبية قبلي } & \\
\hline & & & & معياري & متوسط & معياري & متوسط & \\
\hline دال عند & $\ldots$ & $1 \%$ 14. 9 & (גד & $1, \varepsilon 1$ & Ir.AV & $1, \wedge \varepsilon$ & 9.9. & \\
\hline
\end{tabular}

يتضح من الجدول السابق وجود فرق ذو دلالة إحصائية بين متوسطي

درجات التطبيقين (القبلي والبعدي) في المجموعة التجرييية في مهارات التواصل الاجتماعي المتضمنة ببطاقة الملاحظة ؛ حيث جاءت قيمة "ت " أكبر من القيمة الجدولية حيث "ت" الجدولية عند مستوي(ه.,.•) ودرجات حرية

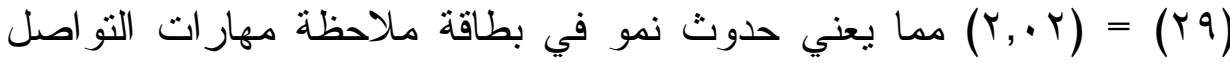
الاجتماعي لاي المجموعة التجريبية؛ مما يذل علي فعالية المعالجة التجرييية من

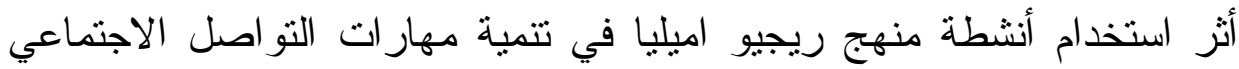
لاي طفل الروضة . تفسير ومناقشة النتائج: أظهرت النتائج صحة الفرض الأول الذي ينص علي: يوجد فرق ذو دلالة إحصائية عند مستوي (0. . •) بين متوسطي درجات أطفال المجموعة التجريبية

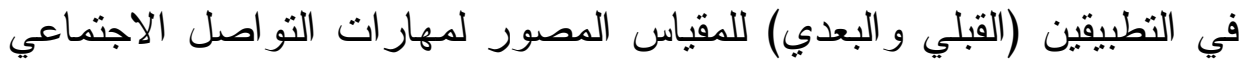

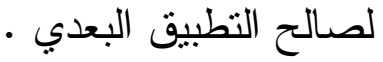


وصحة الفرض الثاني الذي ينص علي : يوجد فرق ذو دلالة إحصائية عند مستوي دلالة ه.,. ، بين متوسطي درجات أطفال المجموعتين (الضابطة

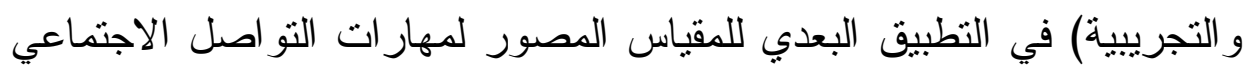
لصالح المجمو عة التجريبية وصحة الفرض الثالث الذي ينص علي: يوجد فرق ذو دلالة إحصائية عند مستوي دلالة ه.,. بين منوسطي درجات أطفال المجموعتين (الضابطة

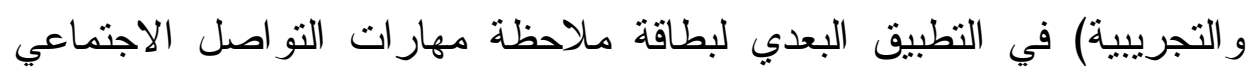
لصالح المجموعة التجريبية وصحة الفرض الر ابع الذي ينص علي: يوجد فرق ذو دلالة إحصائية بين منوسطي درجات أطفال المجموعة التجريبية في التطبيقين (القبلي و البعدي) لبطاقة ملاحظة السلوكيات الاجتماعية لصالح التطبيق البعدي فئي ويمكن تفسير النتائج وفقا لما يلي: لاحئي

قد ترجع الزيادة فى درجات أفراد المجموعة التجريبية فى المقياس

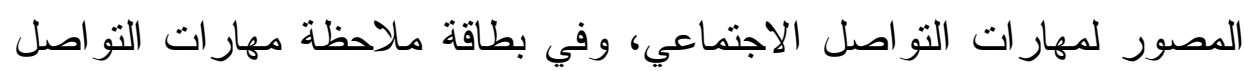
الاجتماعي فى النطبيق البعدى للمقياس إلى الأسباب التالية : تقفوق أطفال المجموعة التجريبية في النطبيق البعدي لمقيــاس الدفــاهيم

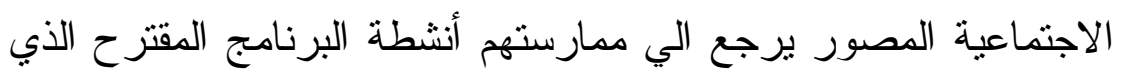

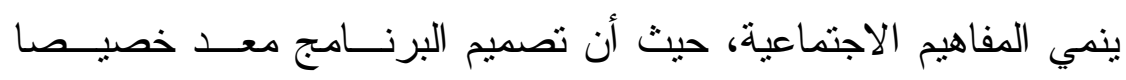

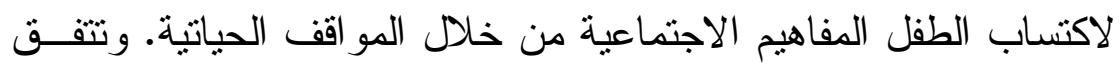

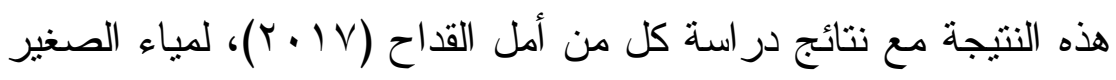

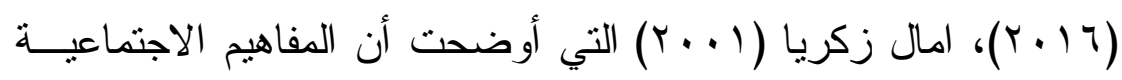

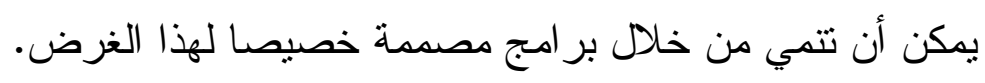




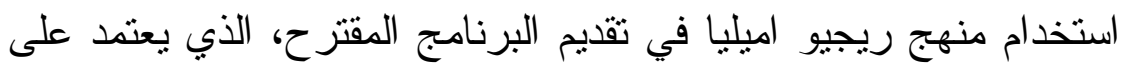

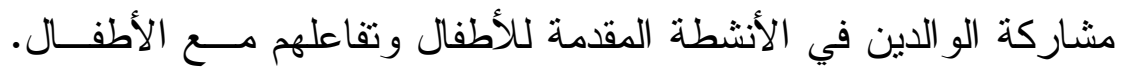

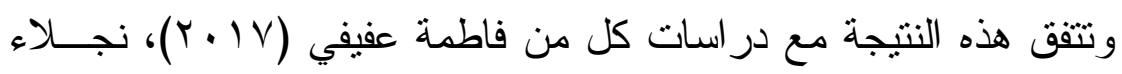

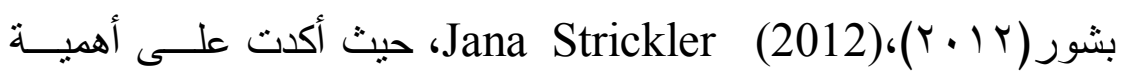

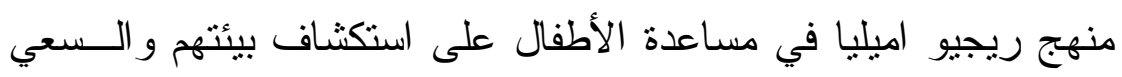
في حل المشكلات التي تقابله، ومشاركة الاباء الفعالة داخل المنهج. الاستخدام منهج ريجيو اميليا القائم على ضرورة المشاركة و التفاعل بـين الأطفال وبعضهم و الأطفال و المعلمة في اكتساب المفاهيم الاجتماعيــة.

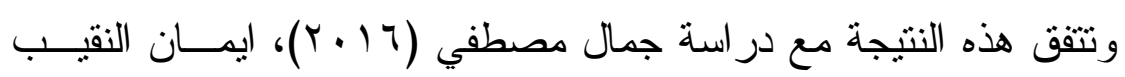

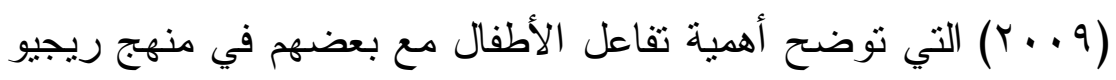

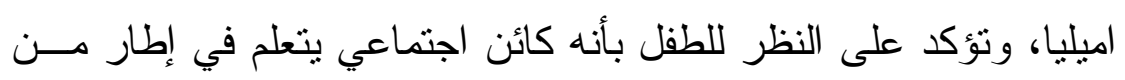
التعاون المشترك بين الطفل و المعلمة و البيئة المحيطة بها. استخدام العديد من اساليب التعليم و التعلم و عدم الاقتصار على طريقة او

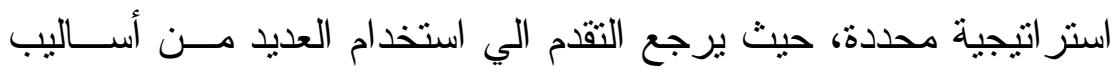

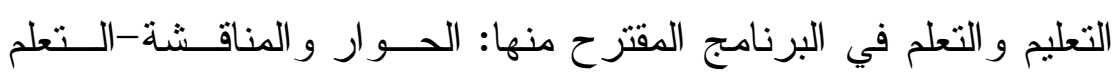

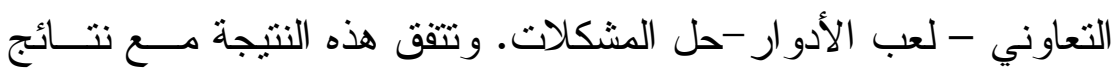

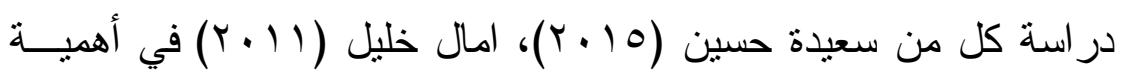
التتوع في الأساليب المقدمة للأطفال لمر اعاة ميول الأطفال و اهنماماتهم.

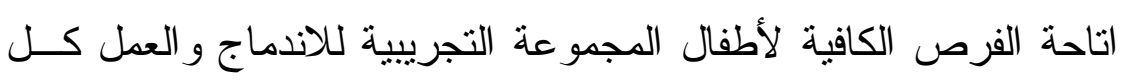

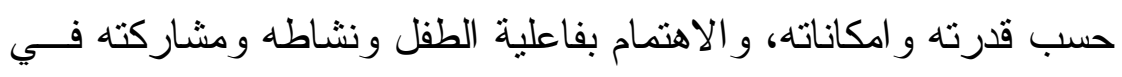

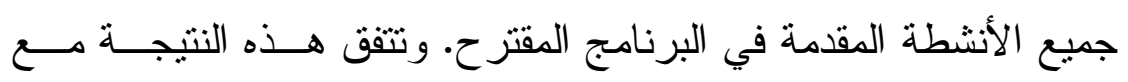




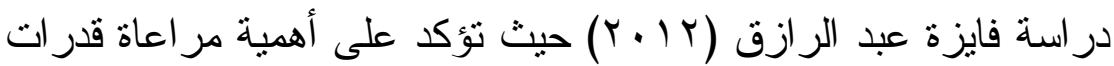
الأطفال و استغلال قدر اتهم في الأنشطة المقدمة.

الاستفادة من المو اقف الحياتية للطفل في تقديم أنشطة البرنامج المقترح ؛

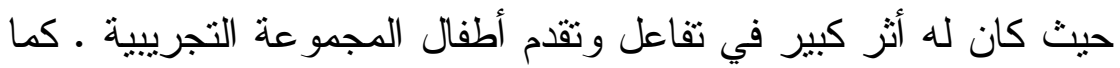

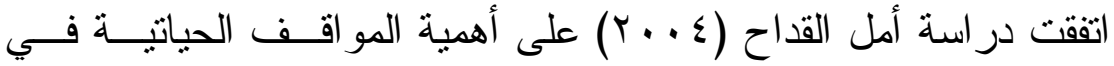
اكساب الأطفال المفاهيم المختلفة.

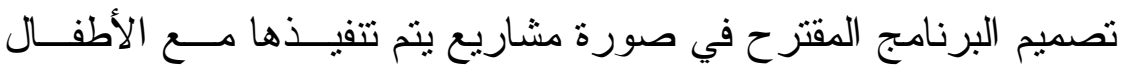

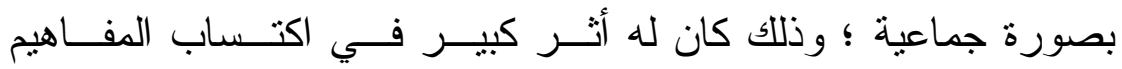
الاجتماعية للمجموعة التجريبية. وتتفق هذه النتيجة مع در اسة داليا همام

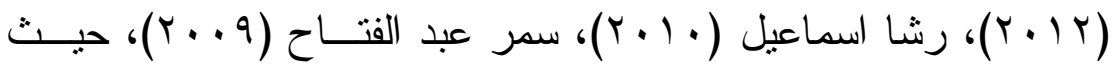

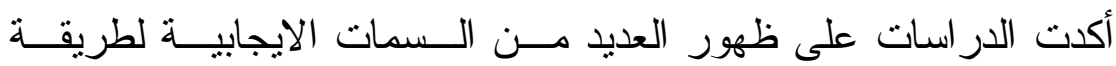
المشرو ع، ومدي مناسبتها لطفل الروضة. اقتزاحات و أفكار الأطفال الظاهرة في تصرفاتهم وتعبير اتهم ثُـم عمـلـل

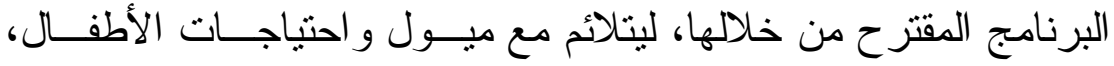
ومثال على ذلك عند متابعة الباحثة للأطفال ذكر الأطفال حبهم الــشديد

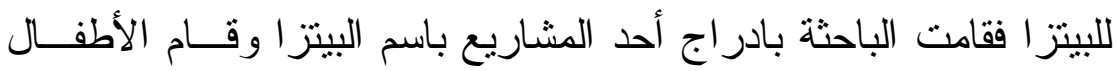

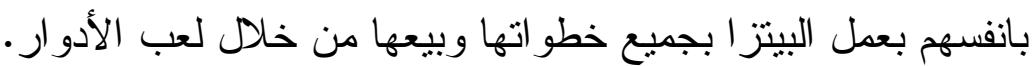

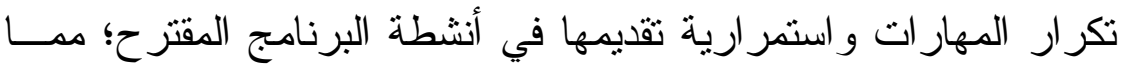

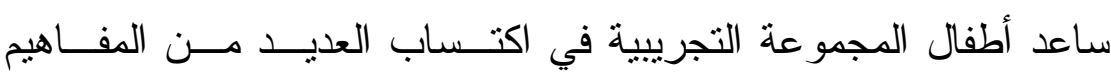

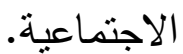




\section{توصيات البحث:}

فى ضوء ما تم التوصل إليه من نتائج البحث فيما يلي مجموعة من التوصيات التي من شأنها إلقاء الضوء على أهمية منهج ريجيو اميليا في نتمية

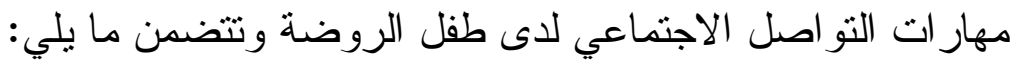

1- إعداد دورات تدريبية لمعلمات رياض الأطفال لتدريبهن على كيفية

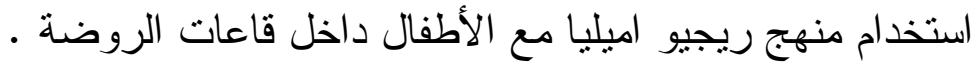

r- ضرورة تضمين أنثطة منهج ريجيو اميليا ضمن المناهج الدراسية المقدمة لطالبات رياض الأطفال كأحد المناهج الحديثة المستخدمة حول النيان

$$
\text { العالم. }
$$

r- ضرورة مشاركة أولياء الأمور مع المعلمات في تقديم الأثطة للأطفال

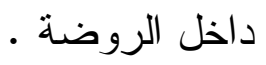

عـ ضرورة توفير بيئة مناسبة للطفل بالروضات للعمل في مشاريع تمتل

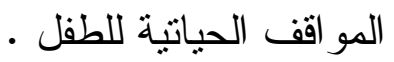

0- تتظيم بيئة الروضة لتلائم قدرات الأطفال الابداعية ، حيث تعد البيئة

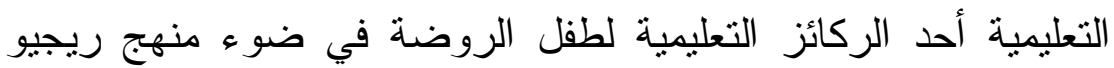

$$
\text { اميليا. }
$$

T- ضرورة الاهتمام بتوثيق أعمال الأطفال ، وذلك لمعرفة مدي اكتساب

$$
\text { الطفل للمهار ات و المعارف المختلفة. }
$$

V- مر اعاة التنويع في مهار ات التواصل الاجتماعي داخل المناهج المقدمة

$$
\text { لطفل الروضة. }
$$


1- أهمية استخدام طرق و أساليب متتوعة ومختلفة للتوثيق منها: الصور ، و الفيديو هات، ورسومات الأطفال ، وكتابة الملاحظات.

9 - ضرورة الاعتماد علي أسلوب المشاريع طويلة المدي وقصيرة المدي في

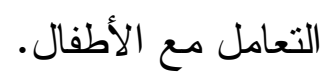

• ا-مراعاة نشر ثقافة المناهج الحديثة ومنها منهج ريجيو اميليا بين

$$
\text { المعلمات علي المستوي المحلي و الدولي. }
$$

\section{البحوث المقترحة:}

استكمالا للجهد المبذول في البحث، تقترح الباحثة مجموعة من الدراسات

$$
\text { المستقبلية المرتبطة بمتغير ات البحث الحالي، كما يلي: }
$$

ا- تصميم برنامج قائم علي منهج ريجيو اميليا لتحقيق مجالات ومعايير

$$
\text { الرياضيات. }
$$

r- تتمية بعض مهار ات التو اصل الاجتماعي باستخدام برنامج مقتر ح قائم

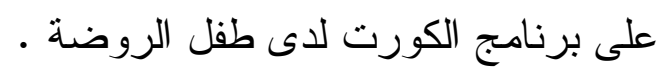

r- برنامج لاعداد الطالبة المعلمة علي توظيف طريقة المشروع في عملية تعليم الطفل.

ع- أثر استخدام مر اكز التعلم في تتمية مهار ات التواصل لدي طفل

$$
\text { الروضة. }
$$

0- برنامج مقترح للتكامل بين معلمات رياض الأطفال و الأسرة في تتمية بعض المهار ات الاجتماعية لطفل الرياض. 


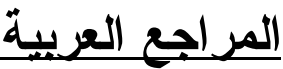

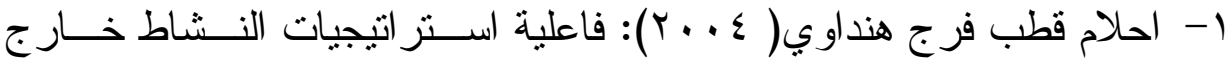
الفصل في تعديل الانماط المعرفية وتتمية المهـــار ات الاجتماعيــة لطفــلـل

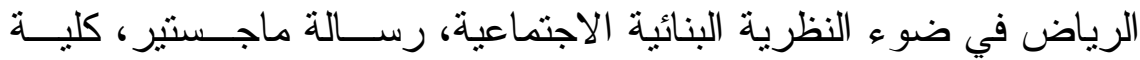

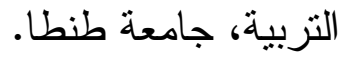

ץ- أحمد جابر أحمد السيد( ( . ب): استخدام برنامج قائم علي نمــوذج الــتعلم

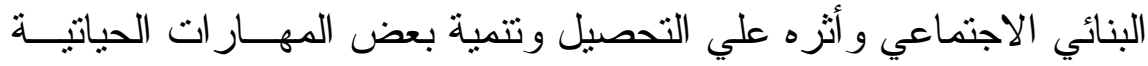

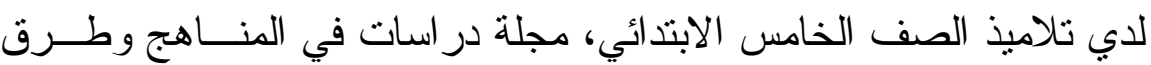

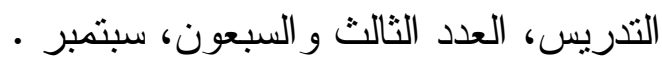

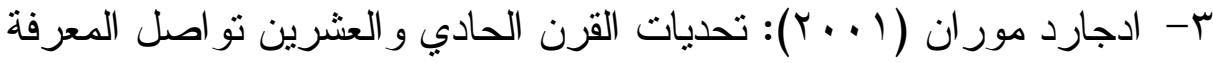
العلمية ، (ترجمة : حسين شريف) ، القاهرة ، الهيئة العامة للكتاب .

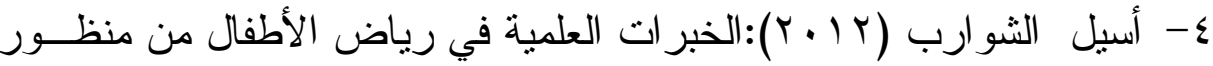
ريجيو اميليا ، مجلة الطفولة العربية، العدد بro، ص

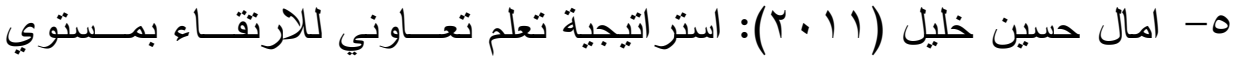

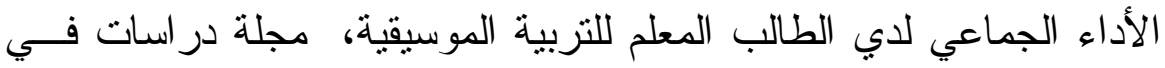
المناهج وطرق التنريس، العدد 79 الأبماعي أبريل.

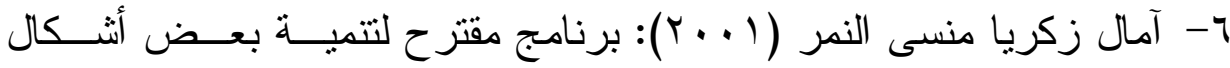

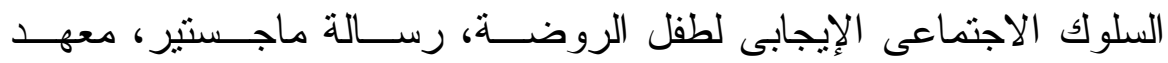
الدر اسات التزبوية، جامعة القاهرة. 


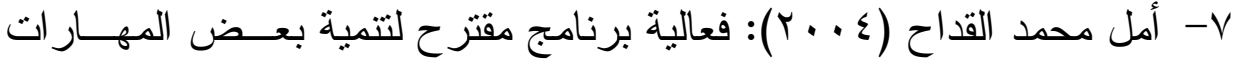
الاجتماعية لاي أطفال الرياض من خلال المو اقف الحياتية ، مجلـــة كليــة

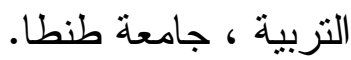

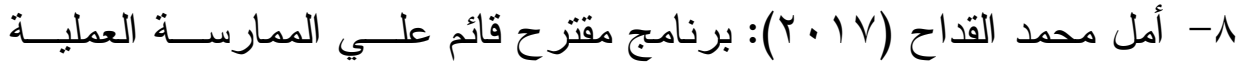

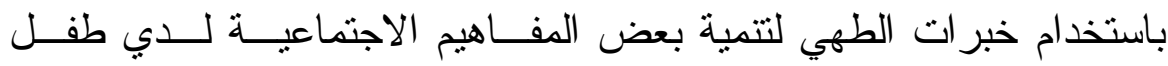

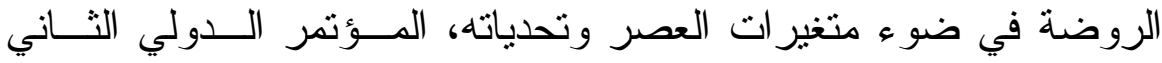

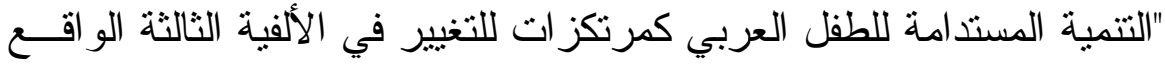
و التحديات"، كلية رياض الأطفال ،جامعة المنصورة، بك ابريل.

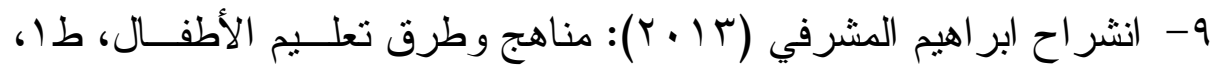
الرياض، دار الزهر اء للنشر و التوزيع.

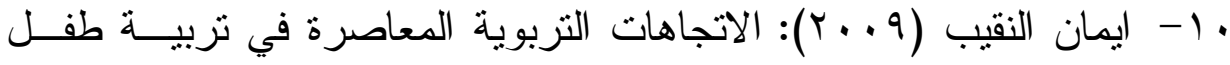
رياض الأطفال : تجربة ريجيو اميليا في ايطالياهمجلة كلية التربية،جامعة

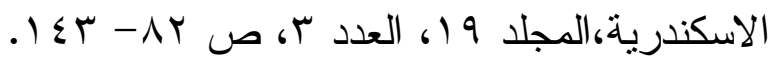

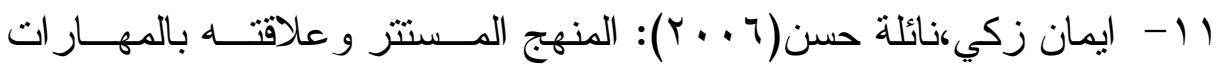

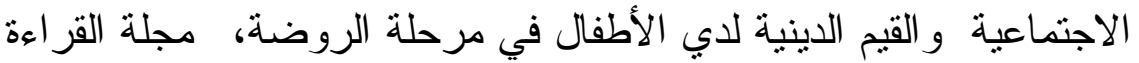

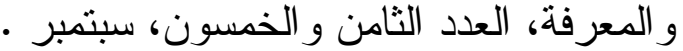

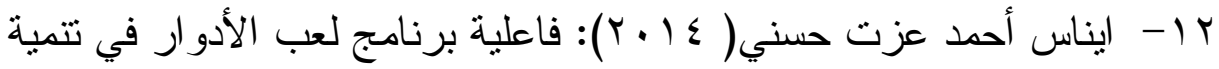

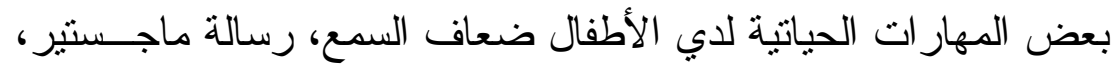
كلية رياض الأطفال ، جامعة القاهرة. 
r ا - جمال مصطفي محمد (T ( • Y): طريقة ريجيو اميليا للتربية في الطفولــة

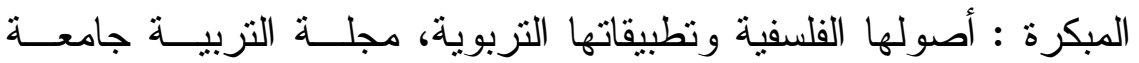

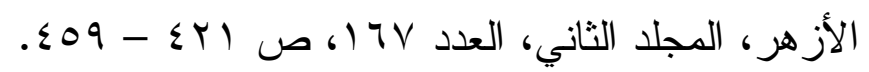

ع ا - جو ان هيندريك ( q . . r) : الخطو ات الأولي نحو تدريس منهج ريجيــو اميليا، (ترجمة : حزم علي و افي)، القاهرة، عالم الكتب.

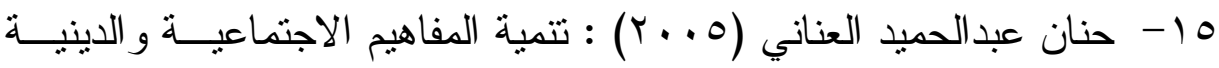
و الأخلاقية في الطفولة المبكرة، عمان، دار الفكر.

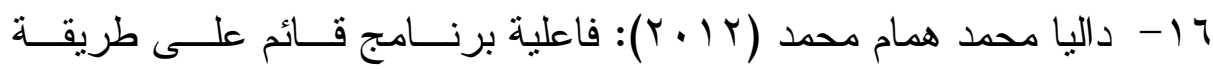
المشروع في تتمية بعض مهار ات ماور اء المعرفة لاى أطفال الروضـــة، الرة رسالة ماجستير ، معهد الدر اسات التربوية، جامعة القاهرة.

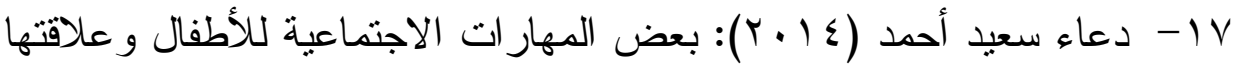

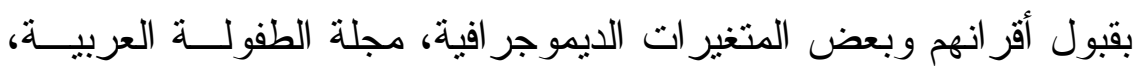

$$
\text { العدد ستون. }
$$

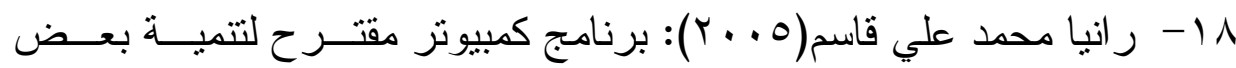
المهار ات الاجتماعية للأطفال مستخدمي الكمبيوتر، رسالة دكتور اه، كليــة رياض الأطفال، جامعة القاهرة.

9 1 - رشا اسماعيل خليل ( • • (r): منهج ريجيو اميليا كمدخل لاكساب طفـلـ الرياض بعض المفاهيم المرتبطة بحقائق الحياة، رسالة دكتـــور راه ، كليـــة رياض الأطفال، جامعة الاسكندرية.

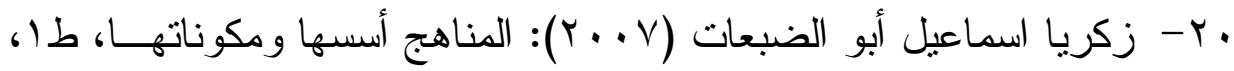
عمان ،الأردن، دار الفكر ناشرون وموزعون. 


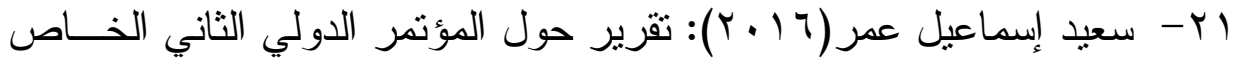

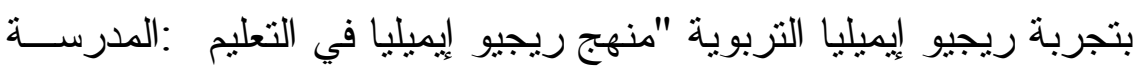

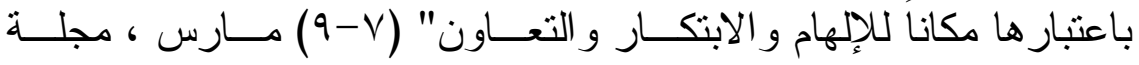

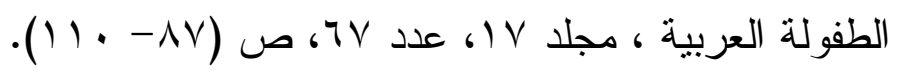
Y Y- سعيدة حسين الدرديري (10 ب ب): نوظيف استراتيجية الـتـعلم التعساوني

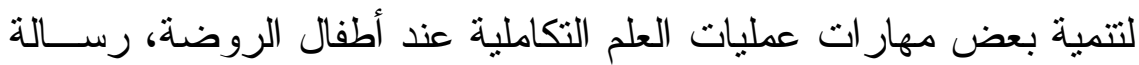
دكتور اة، كلية رياض الأطفال، جامعة القاهرة.

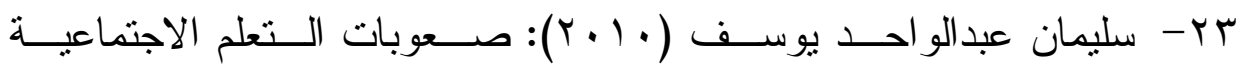

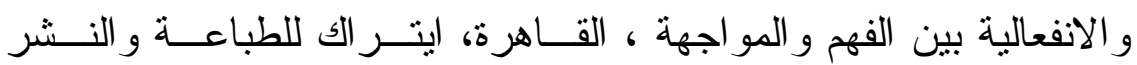

$$
\text { و التوزيع. }
$$

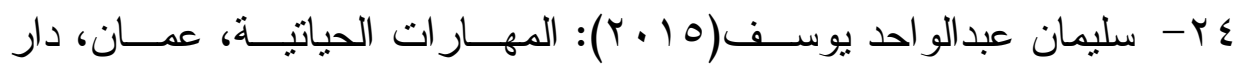

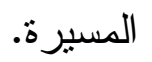

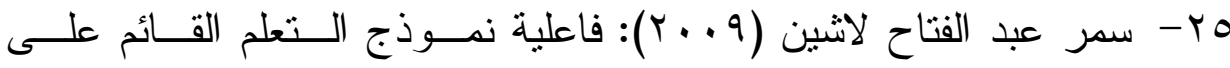

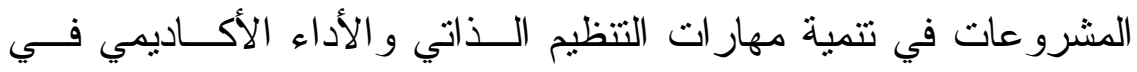

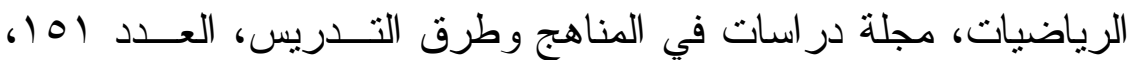

$$
\text { أكتوبر - (الربافن }
$$

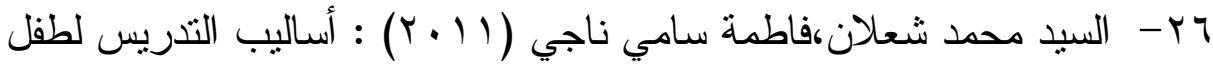
الروضة، طا، القاهرة، دار الكتاب الحديث.

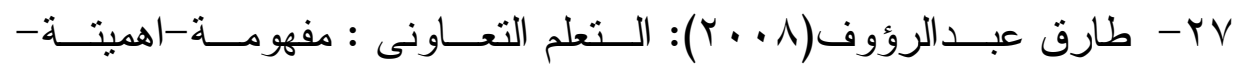
استر اتيجيتة، القاهرة، المؤسسة العربية للعلوم و الثقافة.

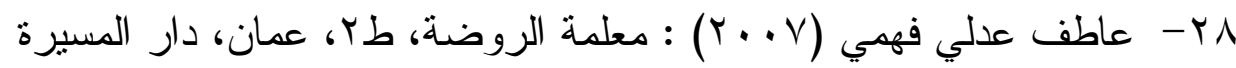
للنشر و التوزيع. 


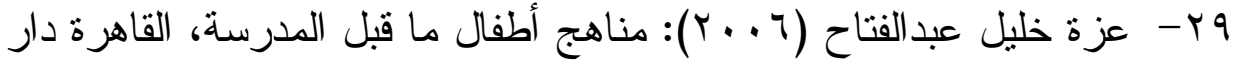

$$
\text { الفكر العربي. }
$$

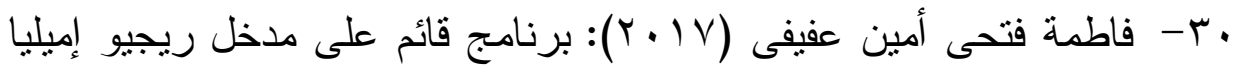

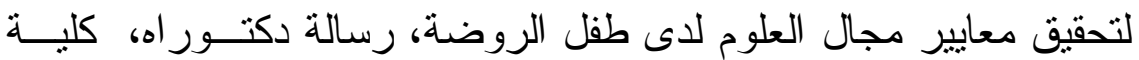
التربية للطفولة المبكرة، جامعة القاهرة.

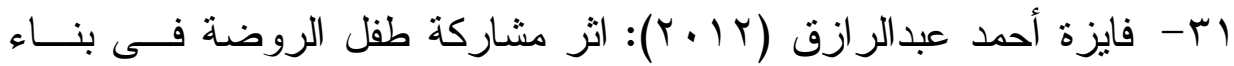
عناصر النص المسرحى فى تتمية بعض مهار ات التعبير اللفظى وغيــر

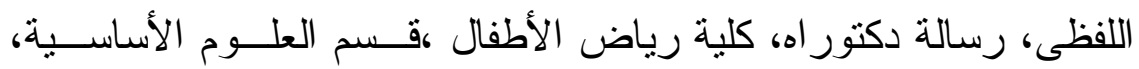

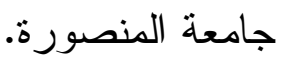

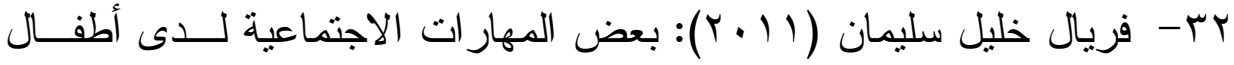

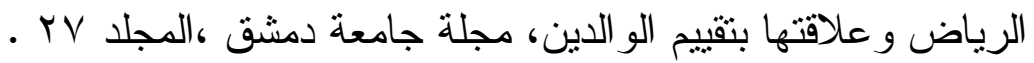

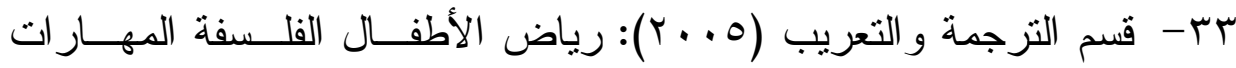

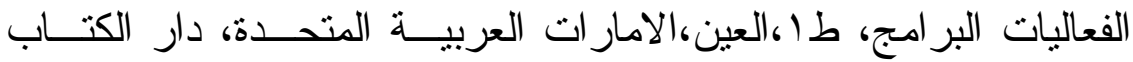

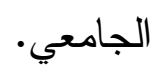

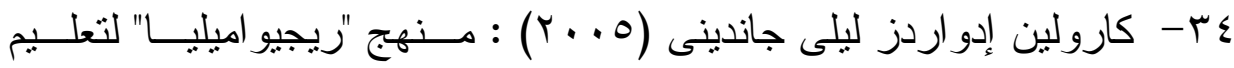

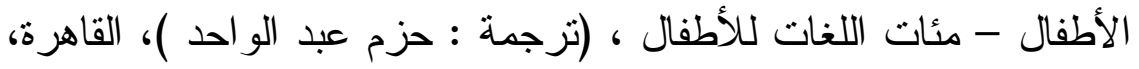

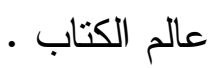

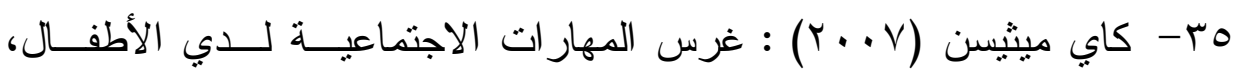
(ترجمة: خالد العمري)، القاهرة، دار الفاروق للاستثمار ات الثقافية.

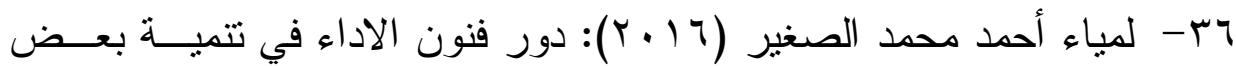

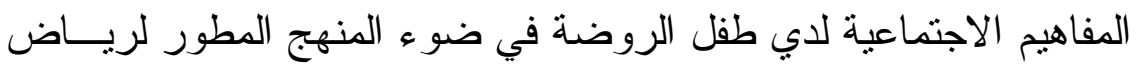

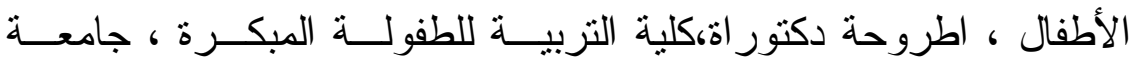

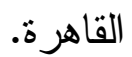




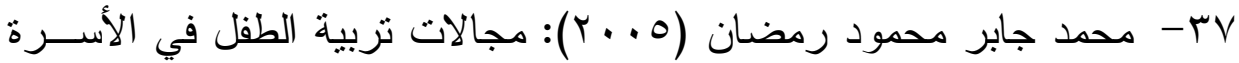
و المدرسة من منظور تكاملي،ط ا، القاهرة، عالم الكتب.

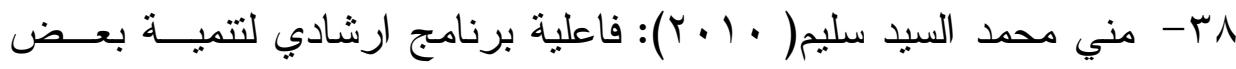

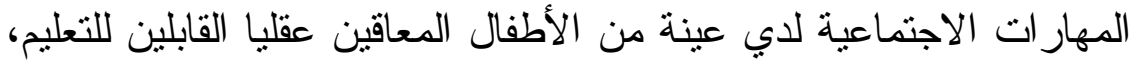
كلية رياض الأطفال، جامعة القاهرة.

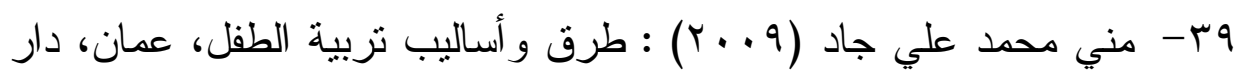

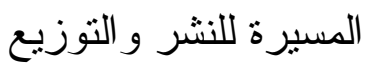

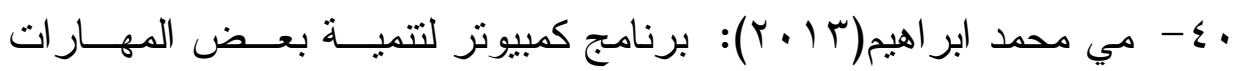

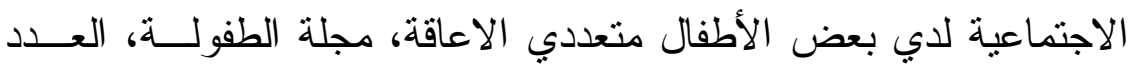

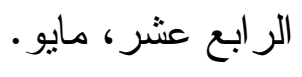

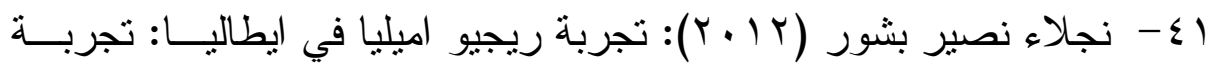

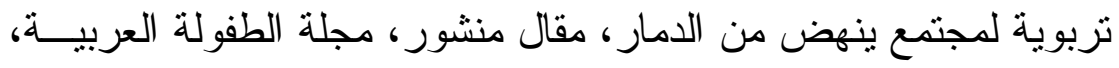

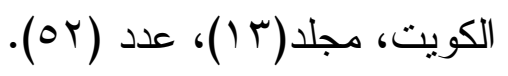

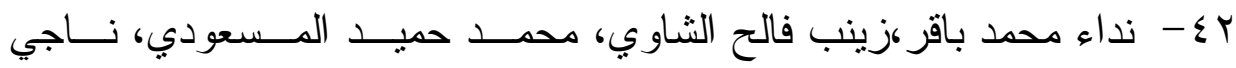

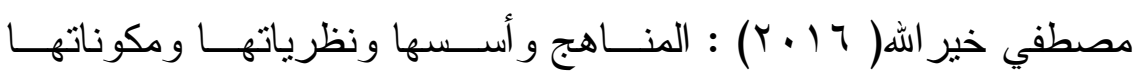

$$
\text { وخطط تدريسها،عمان، دار المنهجية. }
$$

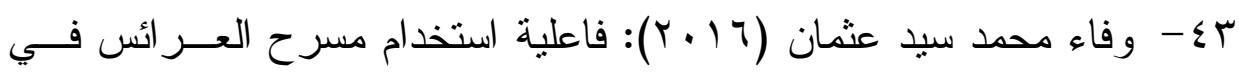

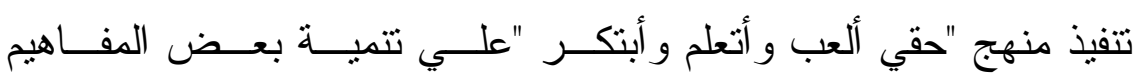

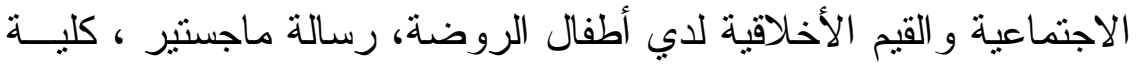

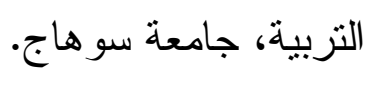




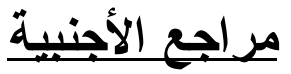

44- Ayla Arseven(2014):THE REGGIO EMILIA APPROACH AND CURRICULUM DEVELOPMENT PROCESS,INTERNATIONAL JOURNAL of ACADEMIC RESEARCH Vol. 6. No. 1.

45- Caitlin S. M. and Catherine W. G.: Parental Reactions to the Introduction of the Reggio Emilia Approach in Head Start Classrooms: Journal of Early Child hood Education, Vol. 26, No.2, 2002.

46- DOROTHY H. COHEN,et (2008): Observing and Recording the Behavior of Young Children, FIFTH EDITION, New York, Teachers College Press.

47- Franca P.: "The play garden: Encounters with aspects of the Reggio Emilia approach to early childhood education" Master dissertation, University of Toronto York, 2007.

48- Jana Strickler(2012):The Educator's Perspective: Implementing the Reggio Emilia Approach in the American Classroom ,MASTER OF SCIENCE, Jackson College of Graduate Studies and Research, UNIVERSITY OF CENTRAL OKLAHOMA.

49- Karen Petty (2009): Using Guided Participation to Support Young Children's Social Development, National 
Association for the Education of Young Children, Vol. 64, No. 4, pp. 80-85, $\underline{\text { URL: }}$ http://www.jstor.org/stable/42730468.

50- Kearns, J., Towles-Reeves, E., Kleinert, H., Kleinert, J., \& Kleine- Kracht Thomas, M. (2011). Characteristics of and implications for students participating in alternate assessments based on alternate academic achievement standards. Journal of Special Education, 45(1), 3-14.

51- Marianne Valentine(2006):The Reggio Emilia Approach to Early Years Education, Learning and Teaching Scotland.

52- Nicole Gardner-Neblett \& Kathleen Cranley Gallagher (2013). More than baby talk: 10 ways to promote the language and communication skills of infants and toddlers. Chapel Hill: The University of North Carolina, FPG Child Development Institute. Available at: http://mtbt.fpg.unc.edu/

53- Sani-Bozkurt, elc (2017): Design and Use of Interactive Social Stories for Children with Autism Spectrum Disorder (ASD), CONTEMPORARY EDUCATIONAL TECHNOLOGY,vol.8, no.1 , pp.1-25. 
54- Suat KOL (2016): The Effects Of The Parenting Styles On Social Skills Of Children Aged 5-6, The Malaysian Online Journal of Educational Sciences, vol.4, no.2, pp.49-58, URL: www.mojDes.net.

55- Susan Clarke (2005): Interpreting the Reggio Emilia approach Implications for reducing violence and aggression in early childhood, Masters of Education, The faculty of graduate studies, York University. 


\section{أثر استخدام الأنشطة القائمة علي منهج ريجيو اميليا في تنمية بعض مهارات التواصل الاجتماعي

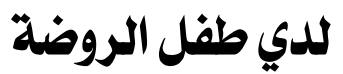

\section{ملخص البحث}

هدف هذا البحث الي التعرف علي أثثر استخدام الأنـشطة القائهــة علـي

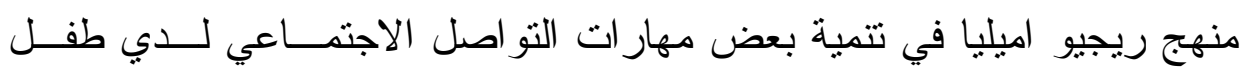

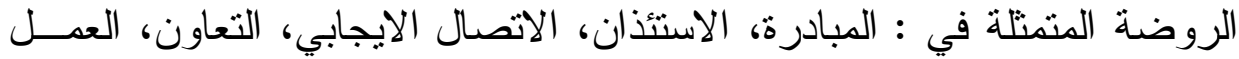

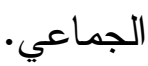

وقد بلغت عينة البحث ( • (7) طفلا وطفلة من أطفال الروضــة تتــر اوح

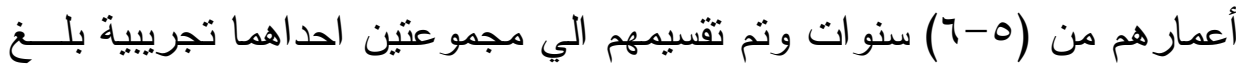

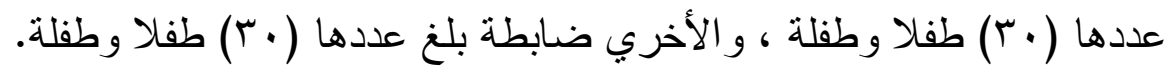
قامت الباحثة باعداد أدوات البحث ، حيث تــم اعــداد اسـتبانة لتحديـــ

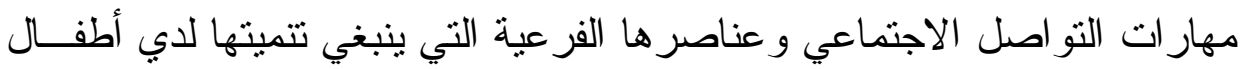

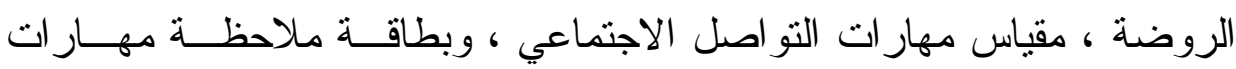

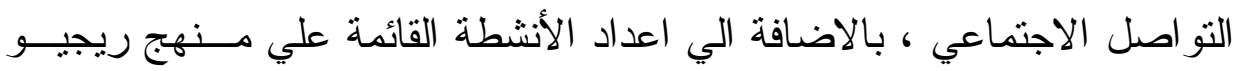

$$
\begin{aligned}
& \text { اميليا التي تتمي مهار ات التو اصل الاجتماعي. } \\
& \text { أسفرت النتائج عما يلي: }
\end{aligned}
$$

1-وجود فرق ذو دلالة إحصائية بين منوسطي درجات أطفال المجمــوعتين

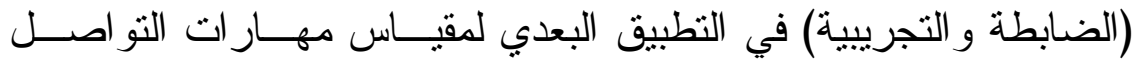
الاجتماعي لصالح المجموعة التجريبية 
ץ-وجود فرق ذو دلالة إحصائية بين متوسطي درجات أطفــال المجموعـــة

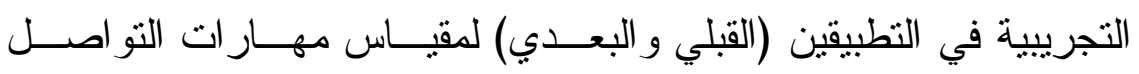

$$
\text { الاجتماعي لصالح التطبيق البعدي • }
$$

ب-وجود فرق ذو دلالة إحصائية بين متوسطي درجات أطفال المجمــوعتين

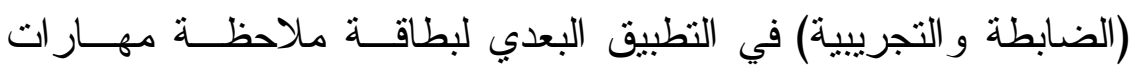

$$
\text { التو اصل الاجتماعي لصالح المجموعة التجريية . }
$$

ع- وجود فرق ذو دلالة إحصائية بين متوسطي درجات أطفــال المجموعـــة

التجريبية في التطبيقين (القبلي و البعـدي) لبطاقــة ملاحظـــة مهــار ات

$$
\text { التو اصل الاجنماعي لصالح التطبيق البعدي • }
$$

